\title{
Rezeption europäischen Rechts in Malawi und Botswana: Die Rolle der afrikanischen Informanten, Richter und Rechtsassessoren ${ }^{1}$
}

\author{
Von Christina Jones
}

\section{Kolonialzeit}

Die Briten übernahmen die politische Macht 1891 in Malawi und 1885 in Botswana. Vom Beginn ihrer Kolonialherrschaft an warben britische Offiziere Führer und Übersetzer als Begleiter an. Diese Rekrutierung nahm in dem Maß zu, wie sie ihre Herrschaft festigten. Für die Zeit bis 1920 kann man nicht von einem systematischen Anwerbeverfahren von .Führern, Übersetzern, Schreibern und Polizisten/Boten sprechen. Dies ist nicht überraschend angesichts der langen Tradition einer unsystematischen Rekrutierung der britischen Kolonialoffiziere selbst. ${ }^{2}$ Die Beweggründe bei der Auswahl afrikanischer Begleiter waren ziemlich willkürlich. Wesentlich war das äußere Aussehen: "Ich fand einen ziemlich intelligent aussehenden, gewandten Burschen und nahm ihn mit." ${ }^{3}$ Dies blieb von den Afrika-

Die Forschung wurde im Rahmen des DFG-Schwerpunktprogramms "Transformation der europäischen Expansion vom 16. Jahrhundert bis zum 20. Jahrhundert. Forschungen zur kognitiven Interaktion europäischer mit außereuropäischen Gesellschaften" unternommen. Das Projekt hat praktische Folgen: Der Chief Commissioner for Traditional Courts, Malawi, war von meinem Vergleichungsprojekt so begeistert, daß er eine Delegation nach Botswana geschickt hat, um regelmäßigen Austausch zwischen den Traditional/Customary Courts Behörden in beiden Ländern zu initiieren.

A.H.M. Kirk-Greene, ed., The Transfer of Power: The Colonial Administrator in the Age of Decolonialisation, Oxford, University of Oxford Inter-Faculty Committee for African Studies, 1979, 174-175 über "Patronage System". S. auch H. F. Morris and James S. Read, Indirect Rule and the Search for Justice: Essays in East African Legal History, Oxford, Clarendon Press, 1972, 11. Vgl. Rhodes House, Dame Margery Perham, Mss Afr s. 1574, Interview Evelyn Baring, Lord Howick, (Indian Civil Service, Governor Southern Rhodesia, Kenya, High Commissioner South Africa) Nov 1969 über Einfluß Gandhis Bewegung auf Rekrutierung: "I was a schoolboy at Winchester, about 1920, just when Gandhi was running the first passive Resistance Movement in India and led to a falling off in the number of people who wanted to go into the Indian Civil Service. And so a number of important people came to schools and made what were really recruitment speeches. The then Viceroy Lord Chelmsford was one ... the other was Lloyd George ... a powerful character."

Frank Hives (District Officer) and Gascoigne Lumley, Juju and Justice in Nigeria, London, John Lane, The Bodley Head Ltd., 1930, 57. 
nern nicht unbemerkt. Afrikaner aus Malawi erfanden zum Beispiel eine Fabel ${ }^{4}$, in welcher sie beklagten, daß die Kolonialherren sich weitgehend von Äußerlichkeiten beeindrucken ließen ${ }^{5}$ und physische Merkmale als oberflächliches $\mathrm{Maß}$ für Intelligenz verwandten. Nach dieser Fabel hielten viele Männer um die Hand einer sehr schönen Frau an, die sie alle abwies, bis eines Tages ein Mann in wunderschönen Kleidern erschien. Sie sagte ihm, daß sie ihn wolle, er aber sagte, daß er weit weg lebe. Weder seine Brüder noch sein Vater oder seine Mutter lebten in dieser Gegend. Die Frau antwortete jedoch, das macht nichts, ich will dich. So gingen sie zusammen fort. Immer wenn es Nacht wurde, verwandelte sich der Mann in eine Hyäne und trieb sich mit seinen vierbeinigen Freunden herum. Eines Nachts wachte die Frau auf und stellte fest, daß er verschwunden war. Daher schnitt sie seinen Hyänenschwanz ab. In der nächsten Nacht kam der Mann als Hyäne mit allen seinen Freunden, um nach dem Schwanz zu suchen. Die Frau versteckte sich unter der Bettdecke und tat so, als ob sie schliefe. Am Morgen lief sie davon. Die Moral war, daß die Europäer, wie die Frau in der Geschichte, nur Menschen danach auswählen, die feine Kleider tragen oder hübsche Gesichter haben, ohne zu bemerken, daß sie Hyänen mit sich nehmen, die sie bestehlen wollen. ${ }^{6}$

Mit der Zeit jedoch wurde die formale Bildung das Fundament für eine Beschäftigung bei einem Europäer. Die Motivation für den Schulbesuch bestand jedoch nicht in einer zukünftigen Beschäftigung bei Europäern. Sie leitete sich vielmehr her - wie es ein fast achtzigjähriger Häuptling in Malawi erzählte ${ }^{7}$ - von einer jungenhaften Begeisterung, sich mit anderen zu messen. Wenn ein Junge in einem bestimmten Alter gelernt hatte, seinen Namen zu schreiben und sich so über die anderen lustig machen konnte, die dies nicht konnten, so war dies eine Herausforderung. In den 30er Jahren gab es nur wenige junge Männer, die nach 6 Jahren Schulbesuch lesen und schreiben konnten. Ein großer Prozentsatz dieser Männer, die später in den Justizdienst gingen, mochten sehr gern das Fach Geschichte und beobachteten außerhalb der Schule ganz genau den rhetorischen Stil der männlichen und weiblichen Vorsitzenden ihres Dorfes bei öffentlichen Versammlungen. Nach der Schulausbildung gingen diese Männer oft nach Zimbabwe oder Südafrika, zum Beispiel als Lagerangestellte in der Privatwirtschaft. Einige hielten die Verbindung zu ihren Landsleuten aufrecht, indem sie hinsichtlich Sprache und Nationalität in einem Gesellschafts(Reisebetrachtungen aus Malawi, 1877): "He is a smooth-faced, intelligent African." Siehe auch Rhodes House, Sir Mark Wilson (Uganda; High Court Judge, Tanganyika, 1st Class Honours, King's Inn, Dublin), Mss Afr s. 592, Death Report, Criminal Session 24/1946 Rex v. Musuhubi s/o Muhinguzi: "Accused is simple looking unsophisticated type of African."

Rhodes House, W.T.C. Berry a.a.O. Interview, Dez 1993, mit Häuptling, Mzimba South in Embangweni (Malawi). 
verbund im Ausland lebten. Durch diese Verbindung mit ihren Landsleuten wurden die Heimatdörfer über das Ansehen und die Führungsqualitäten ihrer ausgewanderten Söhne informiert. Das Heimatdorf zu verlassen, scheint hoch angesehen für Männer gewesen zu sein, die aus Familien kamen, in denen es Tradition war, die Dorfvorsitzenden, Ratsleute oder Häuptlinge zu stellen. Denn die Gewohnheiten der Ngoni im nördlichen Malawi wollten es, daß der erstgeborene Sohn der zweiten Frau in die Welt hinausgehe und ein Dorf gründe, damit die Ältesten beurteilen könnten, ob er als möglicher Nachfolger eines Häuptlings oder Beraters Führungsfähigkeiten habe. In Botswana wollten die Häuptlinge unbedingt selbst lesen und schreiben können, damit sie die Kontrolle über Verhandlungen mit den Kolonialverwaltern behielten. ${ }^{8}$ Nach ihrer Rückkehr nach Hause konnten diese jungen Männer, soweit sie hart gearbeitet, sich aus der Politik herausgehalten und einen guten Ruf wegen ihrer Fähigkeiten erworben hatten, Streitigkeiten in der Gemeinschaft, in der sie im Ausland lebten, zu schlichten, erwarten, in ihrem Heimatdorf Richter eines afrikanischen Gerichtes zu werden.

Aber die gerichtliche Struktur, zu der sie im Dorf zurückkehrten, lag nicht länger ausschließlich in den Händen der Häuptlinge. Denn die Gegenwart einer ersten Generation des Lesens und Schreibens mächtiger Afrikaner traf in den 30er Jahren mit der offiziellen Einführung der Indirekten Herrschaft im östlichen und südlichen britischen Weltreich zusammen. Die Indirekte Herrschaft bedeutete, daß das alte britisch-indische System, einen britischen District Officer zu haben, der für alle Einwohner und Dörfer in einem bestimmten Gebiet zuständig war, nun auf Afrika angewendet wurde. ${ }^{9}$ Alle Einsprüche an höhere Instanzen mußten über ihn laufen (wobei er dann bei den Entscheidungen der höchsten Kolonialbehörden, die speziell seinen Distrikt betrafen, nicht immer hinzugezogen wurde). Er war Steuereinnehmer, Straßenbauer, Polizist, Staatsanwalt und Richter. ${ }^{10}$ In Malawi und

Schriftliche Gesetze erlassen von König Khama III (1875-1923) und Chief Seepapitso (19101916). Siehe I. Schapera (ed.), The Political Annals of a Tswana Tribe: Minutes of Ngwaketse Public Assemblies 1910-1917, Cape Town, Communications from the School of African Studies, University of Cape Town, 1947.

9

Rhodes House, Dame Margery Perham, Interview Evelyn Baring, a.a.O., 3: "I brought from India the idea that the key to administering a turbulent country was what Africans called District Commissioners, in old Indian Regulations, the Collectors: the central Government's agent on the spot, the equivalent really of the Préfect in France." Vgl. Morris and Read, a.a.O., 261, aber ohne Hinweis auf Indien. Kirk-Greene, a.a.O., 56: Sir Cameron führte in den 20er Jahren eine Studie über die Arbeitsweisen von Stämmen mit oder ohne Häuptling durch.

10 Subordinate Courts Ordinance No. 5 of 1906 (Nyasaland), §3: "District Courts ... shall with jurisdiction over all Europeans and Asiatics in the district be held by District Residents at the Chief Station in each district ..."; §10: "District Native Courts ... with jurisdiction over all natives in the district shall be held by Assistant Residents."; District Administration (Native) Ordinance No. 13 of 1912 (Nyasaland), §4.(2); §5: "The Principal Headman is responsible to the District Resident ... [and] for promulgation of laws affecting the native population in such manner as the District Resident shall indicate ..."; Native Administration Proclamation No. 74 of 1934 (Bechuanaland), §15.(1); §17.(1)(r): "It shall be the duty of every Chief or Sub-Chief to comply 
Botswana mußten alle wichtigen Streitigkeiten um Land und Stammesherrschaft von ihm gehört werden. ${ }^{11}$ Widersprüche an die höhere Instanz des High Court waren nur über den District Officer möglich. Mit anderen Worten, der District Officer wurde oberster Häuptling in seinem Distrikt und konnte Männer zu Häuptlingen machen oder sie absetzen, indem er über ihren Charakter, ihre Gewohnheiten, Beliebtheit und Kooperation mit dem Kolonialregime berichtete. ${ }^{12}$

Um all diesen unzähligen Funktionen nachzukommen, deren Umfang mit der Einführung von Straßen, der Wanderarbeit, der Suche nach Bodenschätzen, der Plantagenwirtschaft usw. zunahm, mußte der District Officer einen festen, ihn unterstützenden Mitarbeiterstab um sich sammeln. Mit der Einführung der Indirekten Herrschaft bestand der unterstützende afrikanische "Stab" des District Officer, zumindest aus seiner Sicht, aus zwei Komponenten. Die eine waren die Mitarbeiter, die er beschäftigen, anwerben und entlassen konnte, und die andere bestand aus den existierenden traditionellen Verantwortlichen aus jedem Dorf, deren Amtsenthebung politische Konsequenzen hatte. Der District Officer mußte

with all laws and to carry out such lawful orders ... as may ... be given to him by the Resident Commissioner personally or through the Magistrate of the District."; §18.(1)

Subordinate Courts Ordinance No. 5 of 1906 (Nyasaland): "§10; § 15: "All important native cases relating to land, and all disputes between native chiefs of such importance (more than District discipline) shall be tried in the District Native Court or High Court, unless the Governor shall otherwise direct." Dies wurde nach der Unabhängigkeit fortgesetzt: Laws of Malawi, Cap. 3:03 Traditional Courts) (1977), Jurisdiction (Exclusion Notice): "The Minister has ... excluded from the jurisdiction of all Traditional Courts any proceedings involving chieftainship or headmanship or involving the allocation of land under local custom."

Rhodes House, P.L. Burkinshaw (Nyasaland), Mss Afr. s. 1396-1410: Handing Over Notes, H.R.M. Beattie to Burkinshaw, 25.09.1953, Makali, on confidential file on paramount chiefs in the district: "The paramount Chief and the Native Administration Court ... require support." Burkinsahw to D. G. Reid, 14.08.1954, Koinadugu: "I just dismissed two headmen ... for slackness. The other headman ... appears to control his men well." Burkinshaw to J. Watson, Bombali, n.d.: "Considerable jealousy between $\mathrm{K}$. and B. the former chiefdom headquarters which the present chief tends to neglect ... M. is chief only in name and rarely opens his mouth or takes part in chief dom matters. A., headman, ... is forceful character. The N.A. [Native Affairs] Court is one of the best in the district." Siehe auch Rhodes House, G. P. Waddell (Uganda), Mss Afr s. 1784 (72a): Ein außergewöhliches Exemplar eines vom District Officer (T. Preston, Cpt. Tufnell, A. R. Tucker, Lamb, N.E. Bluse, 1926-1947) geführten offiziellen Rotbuches über die Persönlichkeiten der Häuptlinge und die Gründe für deren Entlassung oder Begründung der Einstellung von Assistenten für manche Häuptlinge in Uganda. Es läßt sich vermuten, daß alle District Officers in anderen Kolonien ähnliche Rotbücher führten. Rhodes House, Maurice C. Hoole (District Officer, Nyasaland), Mss Afr s. 997(3), to Provincial Commissioner, Lilongwe, 18 Jan 1938, on Reorganization of Native Administrations: "... I sympathize with chiefs adversely affected [dismissed], but considerations of loss of prestige of an individual chief or family should not be allowed to prevail over interests of the District as a whole." Kirk-Greene, a.a.O., 80. Sir Charles Rey, Monarch of all I Survey. Bechuanaland Diaries 1929-1937, Gaborone, The Botswana Society, 1988, 45: "I had arranged for him [son of Chief Mathiba] to come down here to be educated and to have six months preliminary military training with our police ... It's a great success, and now I hope to have a Chief in the making who will be a lot better than some of the rotters I have now." 
beide "Mitarbeiterstäbe" in einem System differenzierter, hierarchisch geordneter Funktionen organisieren, um sein tägliches Pensum zu erfüllen und sich der zunehmenden Büroarbeit zu entledigen. ${ }^{13}$ Seine Auffassung von den ersteren als seinen Angestellten wurde durch die Tatsache verstärkt, daß er ihnen Löhne oder eine regelmäßige Besoldung zahlte. Aus der Sicht der afrikanischen Verantwortlichen bedeutete der Umstand, ein Gehalt zu bekommen, jedoch nicht unbedingt, sich als Teil einer Mitarbeitergruppe des District Officer zu verstehen. Anders ausgedrückt, mit den Worten der von mir zuvor erwähnten Fabel, einige nahmen die Gehälter, ohne jedoch unbedingt eine auf einer monetären Beziehung basierende Unterordnung zu verinnerlichen, weil es für sie andere familiäre und politische Loyalitäten innerhalb des Dorfes zu beachten gab. Jene britischen Offiziere, die dies nicht bemerkten, reagierten mit Brutalität. ${ }^{14}$ Jene, die aufmerksam genug waren, pflegten persönliche Beziehungen, in denen Charakter und Ehre des Wortes hervorgehoben wurden. ${ }^{15}$

1 Nyasaland Protectorate Law Reports (1928) 72, Bwakuonera v. Taimu (Appeal), Haythorne Reed, J.: "The Magistrate said that according to his custom in civil cases, when he is busy and to save natives being from kept waiting, he instructed a native clerk to take down the statements of the parties and their witnesses, and when this was done, he read them out in Court, and entered it in the Court book, giving each party every facility to call witnesses and question them. The questioning of witnesses and recording their evidence is an important part of the hearing of a case and must be done in open Court ... and a Magistrate ... in this case has, without any right to do so, delegated a substantial part of the hearing to his native clerk. Obviously, this is wrong, for even if the statements are correctly recorded, the Magistrate has had no opportunity of observing the witnesses and the way they give their evidence. If the case had been between two Europeans, one cannot imagine a Magistrate sending his European clerk ... to take down the statements of the parties and their witnesses ... Case to be reheard by the Provincial Commissioner of the Central Province."

14

Rhodes House, Sir Horace Archer Byatt, Mss Brit. Emp. s. 388, Diary (Nyasaland, 25 and 27 March 1901). S. auch Griff Jones (Administrative Office, 1952-61, Nyasaland), Britain and Nyasaland, London, George Allen and Unwin, 1964, 228.

Volkscharakterologie und völkerpsychologische Theorien über Entwicklungsanlagen in den verschiedenen Kulturen und Menschen prägten vor dem Ersten Weltkrieg manche Kolonialbehörde, aber danach setzten sich die strukturfunktionalistischen Theorien Malinowskis ("innere Symmetrie und Vernunft aller sozialen Transaktionen und Institutionen") allmählich durch (s. Max Gluckman, Order and Rebellion in Tribal Africa. Collected Essays with an autobiographical introduction, London, Cohen and West, 1963, 207ff). Vgl. Rhodes House, Wilson, a.a.O. (8/1/87), 11: Memo by the Secretary for Native Affairs Tanganyika, Definition of Native and Position to be assigned to Half Castes (n.d.). Interview mit Sir Bryan Roberts, ehemaliger Staatsanwalt Nyasalands, und Vertrauter ehem. Präsidenten Banda, Jun 1994; Roberts, a.a.O., Malawi's Progress and Problems since Independence, African Affairs, vol. 69, no. 274, 1970, 60-64. Rhodes House, Law Enforcement Nyasaland, Mss Afr s. 1784, Malcolm Llewelyn (1953): "Sergeant at Dedza took kindly interest in me. Sgt. Nmero was illiterate but wise." Law Enforcement, a.a. O., J. M. le Meseurier (n.d.):"... slapping and rough handling of African suspects ... was not allowed in the colonial police force. It did happen sometimes - one Asst. Supt. (European) was dismissed for allowing a sergeant to give a suspect 6 strokes with a cane." Rhodes House, Dame Margery Perham, Interview Evelyn Baring, a.a.O., 20. 
Dies war also der Rahmen, innerhalb dessen gebildete afrikanische Männer ab den 30er Jahren in ihren Dörfern richterliche Funktionen auszuüben hatten. Ihnen standen zwei Wege offen: Ein Weg bestand in einer vollbezahlten Beschäftigung direkt bei der Eingeborenenbehörde ("Native civil service"), die sich von der zivilen Kolonialbehörde ("British colonial service") unterschied. ${ }^{16}$ Der zweite Weg führte zur Übernahme der Funktion einer traditionellen Stellung, die auch ohne die Ankunft der Briten bestanden hätte, nun aber der Anerkennung und Überwachung durch den District Officer bedurfte. Wegen der begrenzten Schulbildung der Afrikaner erwartete man nicht von ihnen, und forderte sie auch nicht auf, in ihrer richterlichen Karriere aufzusteigen. Darüber hinaus gab es außerhalb des Dorfes keine Laufbahn, für die es sich lohnte, sich zu qualifizieren. Denn ihr eigener Status innerhalb der Gemeinschaft ihres eigenen Dorfes bedeutete, daß sie in einer bestimmten Funktion blieben. Ein Dorfführer ("Headman"), der die Position von einem Elternteil geerbt hatte, konnte nie ein Oberhäuptling ("Paramount Chief")werden, und auch ein Berater ("Councillor"), der Streitigkeiten schlichtete, würde nie ein Häuptling werden. ${ }^{17}$

Die Laufbahn der Schreiber/Übersetzer, die für den District Officer im traditionellen Gerichts- und Schiedsgerichtswesen arbeiteten, war dagegen eine andere als die von Söhnen traditioneller Anführer und Berater ("Councillors"). Da sie nicht in Familien von Häuptlingen oder Beratern hineingeboren waren, hatten sie hinsichtlich einer bestimmten Position in ihren Heimatdörfern keine Verpflichtungen oder Erwartungen. Sie waren das Reservoir, aus dem der District Officer Bürokräfte für die polizeiliche Arbeit seines nach britischem Vorbild gestalteten Laiengerichts wie auch für die traditionellen Gerichte in seinem Bezirk schöpfen konnte. Er verließ sich nicht völlig darauf, daß der Häuptling oder der Berater, die bei traditionellen Verfahren den Vorsitz hatten, die Schreibarbeiten erledigten. Er benötigte

Kirk-Greene, a.a.O., 165: "There is ... one branch in which ... Africans should not enter, and that is the [central] Administrative Service." S. 177: "There has been an oblique reference to the role played by European Staff Associations but none to that played by African Staff Associations." S. 34: "Perhaps where we were weakest was that we were not quick enough with training up indigenous civil services." S. 176: Af rikaner dürften kein District Commissioners werden.

Rhodes House, P. L. Burkinshaw (Nyasaland), Mss. Afr. s. 1407(3), Annual Report, 1960, Kasupe District:"African courts: Function satisfactorily ... Growing tendency on part of some chiefs to hand over the actual hearing of cases to their Councillors and to appear only to give a judgment - a practice which is to be deplored." Vgl. hingegen Wilson, a.a.O., 22, Memo. Proposals for post-war developments and improvements in the administration of justice in the Tanganyika Territory: "... unf ortunately the brake which often operated effectively on the chief in former days - the expression of popular opinion through the mouths of the elders - is tending to prove ineffective, it is said now that the chief or headman is becoming more and more a salaried official of Government and looking to it rather than to popular support and recognition for his mandate ..." Vgl. Praxis in Botswana nach Unabhängigkeit in Survey (1988 and 1993), "Frequencies on a few other variables in the chiefs data set to give you an idea of the divided character of their thinking": $58 \%$ of chiefs consult the Kgotla (Gemeindeversammlung); $66 \%$ of chiefs do not consult the elders." (Daten gesammelt von John Holm, Political Science Department, University of Botswana and University of Ohio). 
jemanden anderen, der sich frei umherbewegen konnte. Wichtiger noch, er brauchte jemanden, den er ausbilden und dem er dann die Schuld für mangelnden Erfolg geben, oder den er für seinen Fleiß loben konnte, ohne daß er die politischen Folgen abwägen mußte. ${ }^{18}$ Das Karrieremuster der Schreiber und Übersetzer nahm die Konturen der Kolonialbürokratie an. Mobilität war nötig. ${ }^{19}$ Das bedeutete, daß der Schreiber/Übersetzer oft auf Posten in Gegenden geschickt wurde, in denen der örtliche Rechtsbrauch ihm ebenso fremd war wie seinem kolonialen Vorgesetzten. ${ }^{20}$ Selbst für jene, die hart arbeiteten, um die örtlichen Gesetze ihrer neuen Umgebung zu lernen, war es für das Vorankommen in ihrer beruflichen Laufbahn weitaus wichtiger, daß sie ihr Verständnis des englischen Verfahrensrechts (Ausfüllen von Gerichtsformularen, Protokollieren von Parteivorbringungen, Fernhalten von Zeugen aus dem Gerichtssaal, bis sie angehört würden ${ }^{21}$ oder Niederschreiben von Urteilen) bewiesen, als zu zeigen, daß sie das örtliche afrikanische Recht begriffen hatten. Ihr Einfluß auf die Veränderungen im afrikanischen Verfahrensrecht war gewaltig. Sie mußten lernen, das Verhandlungsprotokoll bei einem afrikanischen Fall nur auf die Erklärungen der eigentlichen Prozeßparteien, ihrer Zeugen sowie des Richters und/oder Sachverständigen zu beschränken, und sie mußten lernen, jegliche Aussagen aus den Reihen der Zuschauer auszuschließen, die sich auf Beweise oder die rechtliche Auslegung von afrikanischen Gesetzen bezogen, die für das Verfahren von Bedeutung gewesen wären. Die Teilnahme des Publikums war dagegen in traditionellen Verfahren wichtig. Ein gewissenhafter Gerichtsschreiber spielte somit eine wichtige Rolle beim Zurückdrängen einer umfassenden Anwendung afrikanischer Vorstellungen in bezug auf die Gewichtung von

18

Interviews, Aug 1993, Aug 1994: 1) Traditional Court Chairman, Chiwenga: "I took over from my granny who was also in the Chamber at one time. My father was a chief in the village." 2) Traditional Court Assessor, Mpherembere: "The Court Chairman's father was an iduna. He had been the Chief's advisor, so people had trust in him." Vgl. Rhodes House, Wilson, a.a.O., über den Fall eines Häuptlings in Tansania, der wegen illegalen Destillierens angeklagt wurde: $C$. W. Ruddick to C. F. Ellaby, 25 Aug 1943, Cr. C. No. 82 of 1943 - R v. (Sub-Chief) Antonini bin Ntambara: "Prosecutor: The District Commissioner has requested that action against Mwami Anton be left in his hands - on political grounds. Please inform Magistrate accordingly and apply for permission to withdraw the charge (in possession of native intoxicating alcohol (moshi))."

19

Interviews mit Clerks Traditional Courts, Sheriffs Magistrates Courts, ehem. Court Inspectors (Malawi, Botswana). Vgl. Rhodes House, Wilson, a.a.O., Resident Magistrate to Registrar, High Court, Dar es Salaam, 31 Jan 1941: "I bring attention to continuous bad behaviour shewn to me by Mr. Kassamali, Court Clerk, Arusha ... Real grievance is that Kassamali wants to come to Moshi which is his home ..." Att.-Gen., 6 Feb 1941: "Court clerk is hardworking, but has inflammable temper, lack of self-control, and want of tact. Request he be transferred to other sphere." B. Pachai (ed.), Memoirs of a Malawian: The life and reminiscences of Lewis Mataka Bandawe, Blantyre, Christian Literature Assoc. in Malawi (CLAIM), 1971. E.A.M. Mangenya, Discipline and Tears. Reminiscences of an African Civil Servant in Colonial Tanganyika, Dar es Salaam, Dar es Salaam University Press, 1984. Hingegen, Kirk-Greene, a.a.O., 54.

21 Interview, Dez 1993, mit Traditional Court Clerk, Luzi, Malawi.

In Malawi hängt ein großes Schild an allen traditionellen Gerichtsgebäuden: "Zeugen sind draußen zu halten, bis sie zur Anhörung aufgerufen werden." 
Beweisen sowie in bezug auf die Rolle der Gemeinschaft bei der Beeinflussung eines als Laienrichter fungierenden Häuptlings oder District Officer, wenn dieser unter sich ständig ändernden Umständen die Rechtsbräuche auslegte. Die extrem verkürzten Niederschriften von Urteilen unter der Auf sicht eines District Officer auf der Dorfebene spiegeln wider, daß die afrikanischen Gerichtsschreiber die prozessuale Verengung des rezipierten englischen Rechts verinnerlicht hatten. $\mathrm{Da}$ ein Gerichtsschreiber ein besonderes Interesse daran haben könnte, die gut funktionierenden afrikanischen Rechtsbräuche aufrechtzuerhalten, konnte aufgrund des Karrieresystems kaum erwartet werden. Die Karrieremuster, wie sie von der aus Indien übernommenen und auf Afrika angepaßten britischen Indirekten Herrschaft festgelegt wurden, sahen nicht vor, afrikanische Gerichtsschreiber zu Richtern auszubil ${ }^{-}$ den. ${ }^{22}$ Ebensowenig wurden Dorfführer, Häuptlinge oder deren Berater ermutigt, sich als Gerichtsschreiber ausbilden zu lassen und dann in ihre Dörfer zurückzukehren, um dort als Richter tätig zu sein. Dies bedeutete, daß ein ehrgeiziger Gerichtsschreiber sich keine Hoffnung machen konnte, eine Karriere als Richter zu machen. Eine Möglichkeit zum Aufstieg hatte er nur als Bürokrat in der Gerichtsverwaltung, die nach englischen Rechtsnormen organisiert war. Die Personen, gegen die er sich im beruflichen Aufstieg behaupten mußte, verstärkten ebenfalls die Notwendigkeit, seine Kenntnis des englischen Rechts zu beweisen. Die schärfsten Mitbewerber waren Inder, die üblicherweise afrikanischen Schreibern gegenüber bevorzugt wurden und sogar auf einem höheren Posten anfingen. ${ }^{23}$ Nur wenn ein niedrigerer afrikanischer Gerichtsschreiber/Übersetzer die Möglichkeit erhielt, einen indischen Schreiber während dessen Urlaub zu vertreten, einen High Court-Richter auf seiner Rundreise zu begleiten und die Fähigkeit zu beweisen, den Druck seiner eigenen Arbeit zusätzlich zu der des abwesenden Gerichtsschreibers zu bewältigen, konnte er die Aufmerksamkeit eines einflußreichen britischen Richters erlangen und eine Empfehlung für einen höheren Posten bekommen, wenn er persönlich den Richter darum bat. Dies war eine sehr britische Vorgehensweise, da viele der District Officers, die ihren Status von Laienrichtern zu ausgebildeten Richtern ("Magistrates") ändern wollten, ebenfalls die Aufmerksamkeit eines High Court-Richters auf sich ziehen mußten. ${ }^{24}$

Margery Perham, Bilanz des Kolonialismus, Stuttgart, W. Kohlhammer, 1963, 29-30, 35-36; Kirk-Greene, a.a.O., 5. Die Afrikaner hatten es aufgrund des Rassismus noch schwerer als die Inder.

Für ein Beispiel siehe Rhodes House, Wilson, a.a.O., 1946, Lake Province Circuit, to Registrar on African interpreter Henry Mgaya: "He is well up to the standard of a good Asian circuit clerk." Wilson, 15 Feb 1946 from M. Lugemarila, c/o District Court, Bukoba: "Since 16 March 1945 I took charge of court work as court clerk, when Asian court clerk was transferred to Njombe ... I am also court interpreter ... My daily life is that of a bee at its beehive! Bukoba District is laden with crimes and civil cases. Court work requires separate clerk and an Interpreter should be entirely devoted to his work alone ... I hold ... (post) of an Asian clerk with salary of 325/-. Former court clerk used to get $440 /-$ per month. My salary at present is only $98 /-$... I entreat an increase to Shs. 150/- p.m." 
Im Gegensatz zu den Gerichtsschreibern kann man von den Häuptlingen und Beratern ("Councillors") nicht sagen, daß sie ein besonderes Interesse daran gehabt hätten, ihre Fähigkeit, das rezipierte englische Verfahrensrecht oder materielle Recht zu erlernen und anzuwenden, unter Beweis zu stellen. ${ }^{25}$ Dort, wo die Häuptlinge sich straffer Strukturen bedienten, z.B. bei den Ngoni im nördlichen Malawi, den Yao im Mangochi-Distrikt in Malawi und den großen Tswana-Gruppen, befanden sie sich auf Konfrontationskurs mit den Kolonialoffizieren. Die Angst, vom britischen "obersten Häuptling" abgesetzt zu wer-

letters, for he is still busy studying law. I think he does too much, but then there are others to compete with and of course he must keep his seniority." Zum afrikanischen Schreibkraft, vgl. Rhodes House, Wilson, a.a.O., 1946, Notes, Lake Province:"on circuit to Tanga ... in absence of the 2 Asian circuit clerks on leave in India it was suggested that a second African interpreter should accompany me to perform the duties of Circuit Clerk. Henry Mgaya, High Court Interpreter volunteered to carry out the duties of Circuit Clerk in addition to his own as Interpreter. Henry had to get on with clerical work ... typing judgments and death reports, issuing summonses, answering routine correspondence. He is a good careful and fast typist ... cheerful and friendly ... $\mathrm{He}$ is just as friendly with his subordinates as he is with his of ficial superiors, which I like ... [H]e as capacity for work and learning, unusual amongst local Africans ... [H]e could rise high ... He deserves being promoted in grade in local civil service. Put this minute before the Chief Justice on his return from Mombasa ..." Zur Karriere eines Europäers, vgl. Wilson, 29 Jul 1945, G. W. Humphries (District Officer) to Wilson: "For many months in 1940 I was doing all the court work in Tabora. Supposing I go to Mbeya and my court work is not unsatisfactory for an amateur, do you think there would be reasonable chance of my being Acting RM (Resident Magistrate) at the beginning of next tour and an eventual appointment to the Judicial Department after call to the Bar? ... Mr. Lloyd-Blood might support me as he knows my family. (All is) in vain if I have no judge's support. From Colonial Office I understand that they require 5 years experience in chambers in Europe. But I should think 16 years in Tanganyika Territory in District Court work ... is as useful as 5 years in chambers. Regarding experience in chambers I believe only a certificate is required as to time and not how time was spent or work achieved from a reputable barrister. Much of the time might have been spent in a Fleet Street tavern whereas an Administrative Officer from here can point to some hundred court cases tried by himself. If the country progresses, I believe the prestige and authority of District Commissioners will decrease. In a progressing society the old 'Bones of River' ways will not do, and (it) is likely that the prestige and pay of professional magistrates will correspondingly increase."

S. Beispiel einer Empfehlung, Rhodes House, Wilson, a.a.O., 1 Feb 1944, Circuit Bukoba: "Mr. Augustine C. Mutahunjukas asked me to put on record my experience with his work as interpreter ... He has in good measure the gift of appreciating the gist of a question and or extracting a relevant answer even from a difficult witness. His knowledge of court procedure is adequate ... in court ... he is cool, firm and restrained even in dealing with the most unpromising material." Vgl. Wilson's Urteil über einen europäischen Kollegen: "Mr. G.W.S. C-D's work ... used to incur a great deal of criticism from all the judges, but I think it has grown somewhat better. [I] do not think that he has any particular flair for magisterial work and shows a certain tendency to "chance his arm" to proceed without reference to his textbooks, which is most undesirable." Dazu auch Rhodes House, Charles C. Ross (Scotsman, Judge Nyasaland, West Indies, Palestine, etc. 192452), Mss Brit Emp s. 356, Reminiscences, 50-51: "In homicide cases, District Residents had to hear all evidence, send the transcript to the High Court which acquitted or convicted the accused [i.e. passed sentence], I was credibly informed one Resident disliked hearing evidence without pronouncing sentence and used to do so without recording it in his notes, at the same time placing an opera hat on his head if he decided that accused was guilty of murder." 
den, trübte in manchen Fällen die Offenheit eines traditionellen Häuptlings gegenüber der Rezeption englischer Rechtsnormen in seinem Gericht. Aus Angst, abgesetzt zu werden, ließ ein traditioneller Häuptling beispielsweise Leute, die mit den Briten zusammenarbeiteten, laufen, obwohl sie eigentlich hätten verurteilt werden müssen. ${ }^{26}$ Das Verhältnis wurde noch schwieriger durch die Tatsache, daß es kaum die gewünschten Auswirkungen hatte, wenn man dem örtlichen District Officer die traditionellen Rechtsbräuche erklärte; dies führte eher dazu, daß diese Bräuche angeprangert wurden. Einige Häuptlinge hatten aufgrund der Überlegenheit der englischen Polizeikräfte keine andere Wahl, als bei den traditionellen Rechtsbräuchen Änderungen vorzunehmen, jedoch informierten sie die Briten nicht immer darüber, wie das Recht sich verändert hatte. Nach vorkolonialem Ngoni-Recht erbte beispielsweise der erstgeborene Sohn der zweiten Frau die Häuptlingswürde, nicht der erste Sohn der ersten Frau. Der Grund hierfür war, daß die Ehe mit der ersten Frau arrangiert war, eine Zwangsehe, während die Ehe mit der zweiten Frau eine Liebesheirat war. Von dem aus dieser zweiten Verbindung geborenen Sohn erwartete man, daß er den Hof seines Vaters verließe, sein eigenes Dorf gründe, Führungserfahrung gewinne und, wenn er sich als würdig erweise, seinem Vater im Amt folge. ${ }^{27}$ Als aber die

Interview mit dem Yao Häuptling und Assessor (über 80 Jahre alt), Khaya Traditional Court, Jul 1994: "There was an offender under traditional law who was in favour with the British colonialists, he was always favoured. The reason was that they [the chiefs as court chairmen] feared the doom of their chieftaincy; ... the man who was to be tried was not taken [i.e. judged] according to his defence but rather according to the way the chairperson who was representing the District Commissioner consented [i.e. thought best]." Vgl. auch Rhodes House, Wilson, a.a.O., Fall eines Häuptlings, der wegen illegalen Brauens angeklagt wurde: District Commissioner and 1st Class Magistrate J. D. Lawrence to Mr. Justice Wilson, 10 Sep 1945: "There are extenuating matters ... I personally requested the Superintendant of Police not to commence proceedings before the Court until he had again consulted with me ... Sir Donald Cameron laid down the principal [sic] that offences by important Headmen and Sub-Chiefs should be dealt with by the Head Chief, subject to the guidance and advice of the Provincial Commissioner [siehe oben Native Administration Proclamation No. 74 of 1934, Bechuanaland] ... I wished to ascertain to what extent this Sub-Chief was ... involved with the object of saving him from unnecessary humiliation and loss of prestige incurred by a public trial ... I had been a month in charge of the district and it was within my knowledge that the deposition of an important Chief Kalemera of Kianja was under consideration by His Excellency the Governor. It was therefore important to preserve the prestige and authority of such an important Sub-Chief who incidentally was a close relation to Kalemera himself ... I do not consider that you had any right whatsoever to suggest such a thing (collusion with another magistrate) to my Provincial Commissioner without having first directed the question to me." $R$. L. Wishlade, Chief ship and Politics in the Mlanje District, 32 Africa, 1961, 36-45, über die Absetzung eines Häuptlings in Malawi. Athaliah Molokomme, 'Children of the Fence': The Maintenance of extra-marital children under law and practice in Botswana, Ph.D. Thesis, Leiden, African Studies Centre, 1991, 148, über die Nichtverurteilung eines einflußreichen Sohnes in einem Schwangerschaftsfall.

Vgl. Margaret Read, The Ngoni of Nyasaland (1956), London, Frank Cass, New Impression, 1970, 15, 50, 79, 124 (weist ohne Erklärung auf unterschiedliche Regelungen : mal der Sohn der ältesten Frau, mal der Sohn der zweiten Frau). A. Manyuela, The Place and Changing Roles of the Kgotla and Chieftaincy in the History of the Bakgatla, Department of History, University of 
Briten die Auswanderung aus alten Dörfern sowie die Gründung neuer verboten ${ }^{28}$, machte es keinen Sinn mehr, den zweitgeborenen Sohn dem erstgeborenen vorzuziehen. Dies führte im Ergebnis zu einer Änderung der Regeln ${ }^{29}$, vor allem dazu, daß der Erstgeborene, wenn er dazu fähig war, sich durchsetzte. ${ }^{30}$ Vor allem in Botswana wurden einige einflußreiche Häuptlinge von großen Gruppierungen durch ihren Widerstand gegen die Durchsetzung des britischen Verfahrensrechts wohlbekannt. Die britische Protektoratsverwaltung führte die Vorgehensweise ein, daß Berater an den Häuptlingsgerichten aus Notablenfamilien "ernannt" wurden, so da $\beta$ der District Officer eine ernannte Person anerkennen konnte und somit auch, falls nötig, die Macht hatte, diese abzulehnen. Ein Häuptling wehrte sich hiergegen und erklärte dem örtlichen District Officer, daß die Tradition ihm als Häuptling nicht erlaubte, seine Berater zu "ernennen". Die Berater hatten wegen ihres Familienrangs bestimmte rechtsberatende Positionen inne. ${ }^{31}$ Angesichts solcher Feindschaft und ihrer

Botswana, B.A. Thesis, April 1980, University of Botswana MF 306.2MAN, Appendix, Interview No. 2, 3 Aug 1979: "The eldest son moves out to make his own ward then moves back when the father dies."

Um Stammeskonflikten vorzubeugen; Interview, Aug, Sep 1993, Dez 1993, mit Ngoni Häuptling, Mpherembere, und Richter des Traditional Court of Appeal, . Er ist sehr angesehen; sein erster Name bedeutet "Warum sterben alle? Wer tötet uns?" (während der Influenzaepidemie circa 19181919): "The British stopped us from moving about. Because they [thus] changed our way of founding new villages, we could not send out the second son of a chief any more, so we had to change the way of succession." Die ratio einer Regelung fiel weg. S. auch Kirk-Green, a.a.O., 54 [Sir R. Turnbull, ehem. Governor, Tanganyika]: "... the precise reason [of the Outlying Districts Ordinance] ... was ... to stop tribes moving into other tribal areas. If you had helped pick up as many bodies as I have when pastoral tribes moved into each others' areas, you would have realised the cogency of all this." Read, a.a.O., 123 gibt hingegen Landknappheit als Hindernis zum Wegziehen an. Rhodes House, Native Administration, Mss Afr s. 938, 1927-1947: Sibande to Rangeley, 27 Dec 1951: "... the Ngoni Customary law is this: if the head village is increase(d) and large, the heir must have his own village. It was not allowable to reign in his father's village, because the father and the son were not allowed to be buried in one cattle kraal ..."

Als logische Konsequenz und nicht als Willkür oder Interesse an Machtbefestigung zu verstehen. Dazu Max Gluckman, The Reasonable Man in Barotse Law, in Order and Rebellion in Tribal Africa. Collected Essays with an autobiographical introduction, London, Cohen and West, 1963, 178-206. Zu unterschiedlichen Einstellungen zur gewohnheitsrechtlichen "Manipulation" siehe Gluckman, Order and Rebellion, a.a.O., 195 (positiv) und Chanock, Law, Custom and Social Order. The Colonial Experience in Malawi and Zambia, Cambridge, Cambridge University Press, 1985, 47 (negativ).

Vgl. Max Gluckman, Order and Rebellion, a.a.O., 14, 20, 23, 30, über die politischen Konsequenzen, d.h. Bürgerkrieg als Stabilisierungsfaktor: "... Strikingly, this conflict of rules, or alternative interpretation of (succession) rules, lead[s] to war which in time reunites the nation ..."

Botswana National Archives, S 420/8, Councillors, 4 Feb 1935, Paramount Chief Bangwaketse to Resident Commissioner on Administration of Tribunals Proclamation of 28 Dec 1934 [Native Tribunals Proclamation No.75 of 1934]: "... The Chief will [under Proclamation] designate councillors and nominate members of the tribunals ... These are my grave difficulties: ... The choosing of councillors and members of the tribunals is entirely a new procedure and not in accordance with Tswana law and custom ... I fail to see the chief alone should be called upon by legislation to designate and nominate such of his helpers ... This is in relation to the ungazetted chiefs who feel 
eigenen, bildungsbedingt begrenzten Möglichkeiten fühlten sich der durchschnittliche Häuptling und seine Berater nicht dazu verpflichtet, bis ins kleinste Detail auf das Recht bzw. die Gewohnheit ${ }^{32}$ und die Veränderungen, die die europäische Expansion diesen auferlegte, einzugehen.

Die Einführung der Kolonialherrschaft hatte jedoch eindeutig zur Folge, daß ein wichtiger Aspekt des Rechts verschwand, nämlich die Möglichkeit, eine neue Gemeinschaft mit variierten Regeln aufzubauen. ${ }^{33}$ Bevor die Briten verhinderten, daß die Völker ihre Gebiete verließen, konnten die Bewohner eines Dorfes beschließen, daß sie mit ihrem Führer oder

they inherited the positions but have not been gazetted. It is common in all Tswana tribes that there are always family feuds, that is a quarrel between the chief and one or more of his uncles. It is well understood that the chiefs uncles are next in rank and the chief has to seek and consult with other hereditary councillors in the tribe ... The chief's uncle will not tolerate to see a (commoner) hereditary councillor appointed and he left out for some reason or other. In other words, I personally am not able to say who should be councillors and who should not, as all are hereditary ... Now according to the Proclamations, (already existing) difficultures will increase ... The tribe will not under any circumstances accept to have their cases adjudicated by appointed men. The same experience is even prevalent now where men had refused to obey orders from a man appointed over them.." Vgl. Zeitungsartikel, "Customary court presidents should be given same respect as chiefs says district commissioner", Daily News (Gaborone), No. 105, 7 Jun 1994, p. 3. Vgl. für Malawi: Ordinance No. 11 of 1924 (Nyasaland) to consolidate and amend the law relating to District Administration: " $\$$. The District Resident may appoint any number of natives ... living in a village not exceeding 10 to be village councillors ... \$6. A village Headman sitting with or without village councillors as may be prescribed may hold court for the hearing of and determination of civil and criminal cases where the parties or accused persons are natives settled in his village area." Für Botswana: H.J. Stanley, High Commissioner, Explanatory Memorandum on the Bechuanaland Protectorate Native Administrations and Native Tribunals Proclamations, 28 Dec 1934 (in 20 Proclamations and Government Notices (1935), 109): "The Proclamation requires the Chief to tell the Government who his Councillors are ... I feel ... that the time must be coming very soon, if indeed it has not come already, when a Chief will not wish to look for advice only to those who are his Councillors by right of birth according to native custom, but will wish to include among his Councillors other natives whose wisdom, or character, or education or experience would make their advice valuable in the interests of the Chief himself and of the tribe as a whole ... and the Proclamation therefore empowers the Chief, if he so desires any such persons as Councillors in addition to those who are entitled to be his Councillors by right of birth ..."

32 Im Unterschied zu "tradition". S. Eric Hobsbawn and Terence Ranger (eds.), The Invention of Tradition, Cambridge, Cambridge University Press, 1983, 2: "'Tradition' ... must be distinguished clearly from 'custom' which dominates so-called 'traditional' societies. The object and characteristic of 'traditions' including invented ones, is invariance ... 'Custom' ... does not preclude innovation and change up to a point, though ... the requirement that it must appear compatible ... with precedent imposes substantial limitations on it ... 'custom' cannot afford to be invariant, because ... life is not so ..." Martin Chanock, a.a.O., 240, Note 1, setzt sich mit dieser Differenzieung nicht auseinander. Er überträgt die Charakteristika der Tradition auf das Gewohnheitsrecht: "... the customary law is what Hobsbawn has called an 'invented tradition' ..."

33 M. Read, a.a.O., 52: "This separation [from Chief Mbelwa] gave them [this section of the Ngoni] a slightly different set of traditions ..." 
Häuptling nicht einverstanden waren, und sie konnten mit einem anderen Anführer wegziehen und ihre eigene Gemeinschaft mit eigenen Regeln gründen. ${ }^{34}$ Durch die Durchsetzung der europäischen Expansion ging diese traditionelle Freiheit, sich außerhalb des Einflußbereichs einer Dorfgemeinschaft zu bewegen und eine andere Dorfgemeinschaft aufzubauen, verloren. ${ }^{35}$ Das Ergebnis dieses Freiheitsverlustes war die Einführung eines neuen Zwangselements bei der Anwendung des "nicht gesatzten" ${ }^{36}$ Rechts. ${ }^{37}$ Die Reaktionen der traditionellen Richter waren unterschiedlich. Einige fühlten sich gedrängt, dieses Zwangselement zu akzeptieren und dem traditionellen Recht Unveränderbarkeit aufzuzwingen. ${ }^{38}$ Andere versuchten, eine gewisse Toleranz aufrechtzuerhalten, indem sie die Methode "beiden Parteien gefallen" ${ }^{39}$ (Stichwort "Konsensus") einführten, was bedeutete herauszufinden, welche Elemente des traditionellen Rechts zu den jeweiligen Konstellationen von

Siehe Max Gluckman, Property Rights and Status in African Traditional Law, in Max Gluckman (ed.), Ideas and Procedures in African Customary Law, Oxford, Oxford University Press, 255-56 über den Fall eines Dorfvorstehers, dessen Mitbewohner wegen seines stürmischen Temperaments wegzogen.

35 Vgl. Max Rheinstein, Die Rechtshonoratioren und ihr Einfluss auf Charakter und Funktion der Rechtsordnungen, RabelsZ 34 (1970), 1-13 (11)

Vgl. Richard Thurnwald, Die menschliche Gesellschaft: Werden, Wandel und Gestaltung des Rechtes im Lichte der Völkerforschung, Bd. 5, Berlin/Leipzig, Walter de Gruyter, 1934, 1.

Vgl. Thurnwald, a.a.O., 61, 2-5, aber Thurnwald berücksichtigte die Möglichkeit, dem Zwang zu entfliehen, um neue/variierte Zwangsordnungen als gesellschaftliche Stabilisierungsfaktoren zu begründen, nicht.

Für Botswana kann man zum Teil von "Gesetzen" reden, da Chief Khama geschriebene Gesetze erlassen hatte. Für die heutige Anwendung seiner Gesetze siehe In the matter between: Sennye Moloi and Mmakganeka Maleje and Mmakgomo Mapotu and Ntshekang Rankgawana (unreported), Civil Appeal No. F17/1990, High Court of Botswana (Francistown), 29 October 1993: "In or about the year 1875 Chief Khama III of the Bamangwato who reigned until the year $1923 \ldots$ issued an edict ordering his people to abandon the practice of declaring children of a couple illigitimate (sic) if no bogadi..has been paid ... The Customary Court of Appeal ... was firmly of the view following Chief Khama III that none (sic) payment of bogadi is neither here or there and it is not an essential ingredient of a valid marriage though no doubt many Ngwato think its payment cements the bond between the families of the bride and groom." Vgl. Verordnungen von Chief Seepapitso der BaNgwaketse in I. Schapera, a.a.O., 51 (1 Apr 1912): "... Why have you abandoned the custom that is yours. I mean the custom according to which you used to marry? ... You ought to give bogadi." Seite 58 (15 Aug 1912): 1. "Whenever a man [non-Christian] marries your child and you do not know him [well], see that he first gives bogadi. 2. Further it is disgusting to see the "white" children of Europeans in our midst. This practice of [concubinage] must cease." Seite 97 (20 Jul 1915): "I say that [men of] of the maLau and maLwelanaga [regiments] must stop making polygamous marriages. If any of them wants to marry more than one wife, I must be told, so that I can see if it is fitting or not. Should any member of these regiments take an additional wife without my knowledge, he and the woman will be judged according to the law of abduction. [Seepapitso's reason ... was because ... when a second wife was married by a relatively young man he often ... neglect(ed) the first wife and her children.]"

Interviews mit Richtern und Assessoren in Mpherembere (Malawi); Interviews, High Court Assessors, Lobatse (Botswana). 
Fakten, den materiellen und psychologischen Bedürfnissen der streitenden Parteien passen würden, - wobei stets feststand, daß sie nicht mehr die Möglichkeit hatten, auszuwandern und ihr eigenes Dorf zu gründen.

\section{Postkoloniale Zeit}

Anstatt radikale Veränderungen in der gerichtlichen Verwaltung mit sich zu bringen, intensivierte die Unabhängigkeit in Botswana (1966) und Malawi (1964) die von den Briten geerbten Strukturen. Die Gerichtsschreiber, die ihre Karriere unter den Kolonialherren gemacht hatten ${ }^{40}$, sehen sich nun als die Erben ihrer früheren britischen District Officers und Provincial Officers. Die Bezeichnungen der verschiedenen staatlichen Abteilungen änderten sich, aber die Funktion blieb größtenteils dieselbe. Das alte koloniale Judical Department, - das der Exekutive, nämlich dem Gouverneur und nicht dem Gericht der britischen Herrschaft, nämlich dem High Court unterstand -, ist im wesentlichen zum Ministry of Justice in Malawi und zum Ministry of Local Government in Botswana geworden. Dies bedeutet, daß die traditionellen afrikanischen Gerichte unter der Kontrolle der bürokratischen Exekutive bleiben. ${ }^{41}$ Es ist seit der Unabhängigkeit möglich geworden, das

Kirk-Greene, a.a.O., 35: "I [Sir Hilton Poynton (ehem. Permanent Under-Secretary of State, Colonial Office)] think some academic might study how many of the leaders of independent Africa had, in fact, made their way and gained their experience through local government up to the top." Interview, Aug 1993, Deputy Provincial Commissioner for Traditional Courts, Mzuzu: "There has not been much change since the British. Retiring Administrative Commissioners have been appointed to District (Traditional) Courts. Training new persons is expensive."

Vgl. Warnung des britishen kolonialen Richters Wilson, a.a.O. (Rhodes House), Lake Province Circuit, Sep-Oct 1940: Note to Registrar: "... it is entirely improper ... to lodge circuit judge and prosecuting counsel in same building. It is likely to give an entirely false impression to laymen as to how justice is administered. The African, especially, is already far too prone to get the erroneous idea that the Judiciary is part of the ... Executive Government ..." Siehe auch Rhodes House, Wilson, 10 May 1938, G.A. Mitchell to Judge Wilson re: New Circular Confidential No. 2 of 1938 for submitting reports on persons charged with murder; Report A to include report on character of accused, possible motives and local popular opinion: "As an amateur magistrate endeavouring to administer justice I was very surprised to be called upon to report on character of accused before he stood trial, as I felt character and motives might be important issues at trial. I confined my report (A) to a short history of earlier life of accused ... and I added I would submit details of character and motives in Report B in event of conviction. I shall probably receive reprimand from $\mathrm{HQ}$ for not following details, but it is difficult to obey an order as an Administrative Officer which one feels is un just as Magistrate." Seit August 1995 sind die Traditional Courts in Malawi unter der Kontrolle des High Court, aber das Verwaltungssystem der Traditional Courts (jetzt Magistrates Courts) bleibt wesentlich intakt. Alle Berufungen von Traditional Courts kommen vor dem High Court. Das Traditional Court of Appeal wurde Dezember 1993 suspendiert. In Botswana will der jetziger Chief Justice (ehem. Attomey General) seinen Plan, alle Traditional Courts aus den Händen der Exekutive zu nehmen, durchsetzen (Interview, August 1994). 
Ministry of Justice und das Local Government Ministry mit früheren Gerichtsschreibern zu besetzen, da deren Qualifikation durchschnittlich doppelt so hoch ist wie die der Richter und Sachverständigen in traditionellen Gerichten. Sie fungieren wie die ehemaligen District Officers als Mittler zwischen den traditionellen Gerichten und dem High Court.

In Malawi ist das Kontrollsystem besonders hierarchisch organisiert, mit den traditionellen Richtern am unteren Ende und über 600 traditionellen Gerichten und 3.000 Angestellten. ${ }^{42}$ Der malawische Chief Commissioner for Traditional Courts hat seinen Sitz in der Hauptstadt (wie die botsuanische Traditional Courts Commmissioner (eine Frau) ihren Sitz in Gaborone hat), er überwacht die Provincial Commissioners, die die District Commissioners kontrollieren. Diese kontrollieren die Gerichtsinspektoren, welche monatliche Berichte über die Qualität der Urteile, die von den traditionellen Gerichten kommen, schreiben. Ein Inspektor hat durchschnittlich 10 Gerichte, die für ca. 120.000 Einwohner zuständig sind, mit etwa 300 Fällen pro Monat in seiner Zuständigkeit. Die Inspektoren sind der Schlüssel zu der Arbeitsweise des traditionellen Gerichtssystems. Sie haben 12 Jahre lang die englische Sprache erlernt und einen einjährigen Kurs an der Government School of Administration in afrikanischem örtlichem oder dörflichem Recht sowie in englischem Zivil- und Strafrecht absolviert. ${ }^{43}$ Ihre bildungsbedingten Fähigkeiten sichern ihnen eine Laufbahn mit höheren Gehältern zu, als sie der durchschnittliche Richter an traditionellen Gerichten hat, der zur Kommunikation mit der Außenwelt auf den Inspektor angewiesen ist. Ihr Standpunkt beeinflußt die Anwendung des traditionellen Rechts. Denn gewissenhafte Inspektoren finden Entscheidungen der traditionellen Gerichte, die dem geschriebenen Gesetz, Billigkeitsrecht oder britischem Verfahrensrecht zu widersprechen scheinen, genau heraus. Viele Inspektoren haben die Begründung des englischen Verfahrensrechts verinnerlicht, daß Beweise auf die betroffenen Parteien und ihre Zeugen beschränkt werden sollen, weil die Konsequenzen des Gesetzesrechts härter sind als die des traditionellen Rechts: was bei einer Verurteilung bedeutet, daß man das Dorf verlassen und in ein fernes Gefängnis gehen muß; man kann nicht für das Vergehen büßen und trotzdem zu Hause bleiben. ${ }^{44}$ Wenn ein Inspektor einen Fehler in einer Entscheidung gefunden hat, schickt er diese Information hoch bis zum Traditional Courts Chief Commissioner, der, wie ein Berufungsgericht, die Entscheidung des traditionellen Gerichts bestätigen, rückgängig machen oder abändern kann. Wenn "Fehler" häufiger auftauchen, schickt der Commissioner ein Rundschreiben an die Commissioners im Außendienst mit dem Inhalt, wie die

Interviews, Chief Commissioner for Traditional Courts. Offizielle Statistiken nicht vorhanden. Ich habe Inspection Reports untersucht, die diese Zahlen bestätigen.

43

Staff Training College, Pemba. Die Beamten behalten eigene Kopien von "Lectures on Customary Law".

44

Interviews, Jul und Dez 1993: Provincial Commissioner for Traditional Courts and Inspector, Mzuzu; Sheriff, Magistrates Court, Mzuzu (ehem. Traditional Courts Inspector); Traditional Courts Inspector, Mangochi; Chief Commissioner for Traditional Courts, Lilongwe. 
endgültige Auslegung einer traditionellen Regel lauten sollte. ${ }^{45}$ In Botswana ist die Überprüfung des traditionellen Rechts nicht so fein organisiert, obwohl man sagen muß, daß die Unterlagen der traditionellen Gerichte in Botswana bei der Local Government Administration aufbewahrt werden, und daß die Gerichtsverhandlungen in demselben kgotla-Lager (dörflicher Versammlungsort, wo wichtige Regierungsgebäude auch stehen) abgehalten werden, so daß alle Mitglieder der Exekutive und der Polizei alles hören. Ein Assistent des Staatskommissars, der im Local Government Ministry sitzt, überprüft die Entscheidungen der traditionellen Gerichte des gesamten Landes. Es gibt über 375 tradtionelle Gerichte mit mehr als 1.300 Angestellten (Laienrichter, Gerichtspersonal, wie Boten und Schreibkräfte). Er bekommt nur dann die Möglichkeit, traditionelles Recht zu prüfen und abzuändern, wenn sich eine der Parteien bei ihm beschwert. Wenn die Angelegenheit mehr als nur Routine ist, erbittet er Rat vom höchsten Regierungsanwalt, dem in Großbritannien ausgebildeten Attorney General, der das letzte Wort hat. ${ }^{46}$

Eine Praxis übernommen von kolonialen "Judicial Circulars": 5 Nyasaland Protectorate Law Reports (1940-45), 95, Judicial Circular No. 7/1941 (1 Mar 1941), Evidence of Interpreters (signed C. C. Ross, Ag. CJ, a.a.O. (Rhodes House)). Botswana National Archives S436/4 No. 7881 (Court, Judge), Resident Commissioner's Office, Mafeking, 29 Jun 1948 from R.G. Bailey, Registrar, High Court to all Administrative Officers: "Enclosed circular by Judge of High Court: Administrative Officer sits by virtue of $\S 7$ of High Courts Proclamation 1938. In one case it was found after decision that an Administrative Of ficer was associated with police at some stage of preparation of case for the Crown. He must have heard certain details related to the police as to how and what each witness saw ... At trial he was nominated to assist the Judge, but failed to disclose his previous knowledge. He sits as assessor and is improper if he has knowledge ... District Commissioner cannot avoid on occasion acquiring special knowledge with regard to crimes, but where this occurs their disability to function as member of the trial court must be realised. Walter Harragin, Judge, High Court." Rhodes House, Sir Charles Belcher (australisches Jurastudium), Reminiscences as Judge (Nyasaland), Mss Brit Emp 347. Er betonte informale Revision, 212: "... the chief task of the judge lay in revising the decisions of these [lay] magistrates [District Officers]. It was expected that he would visit all stations approximately once a twelve-month, when opportunity would be taken to go through files and discuss informally any cases or subjects of legal interest that the magistrate cared to bring to the Judge's notice. I found afterwards, by experience in the substantive post [sic] ... [it] ... sound, just to keep the subordinate courts gently on the rails and not reverse decisions unless justice demanded it, however easy to upset they might have been on technical grounds."

Of fizielle Statistiken nicht vorhanden. Interviews, Aug 1994, mit Traditional Courts Commissioner und ihrem Stab und Staatsanwalt Botswanas: "We sent 19 Jul 1991 (Ref. L7/62 I (38)) a request to I. Kirby in the AG's Office on \$29(4)g of the Customary Court Procedure Rules. The courts thought that they could express a fine in terms of cattle, or money, if one had no cattle. The recommended interpretation turned out to be a fine can be expressed only in terms of money, but compensation or damages can be in cattle or money." Siehe auch AG's Chambers L7/69II (14), 20 Jan 1978, "The Tribal Land Act 1970 in Relation to the Tribal Grazing Land Programme". 
Die Biographien des Ministeriumspersonals (Commissioners und ihre Stäbe) im traditionellen Gerichtssystem zeigen höhere Ausbildung (bis zum Realschulabschluß) ${ }^{47}$, und einen Karrierestart als Schreiber im Office des Attorney General oder einem niedrigeren Gericht oder im High Court selbst. Was den familiären Hintergrund angeht, so kommen sie meistens nicht aus Familien mit traditionellen Machtpositionen, und sind zu einer Missionskirche oder einer afrikanisch-christlichen Kirche konvertiert. Ihr höheres Bildungsniveau gibt ihnen ein gewisses $\mathrm{Ma}$ an Selbstbewußtsein, zu denken, sie hätten das Recht, das Verständnis der traditionellen Richter vom traditionellen Gesetz zu "verbessern".

Es scheint, daß Biographie und Ausbildungsniveau keinen so starken Einfluß auf ihre Auffassung vom traditionellen Recht haben als auf ihre physische Distanz vom "grass-rootGericht". ${ }^{48}$ weiter sie entfernt sind vom traditionellen Gericht, desto abstrakter ist ihre Auffassung vom traditionellen Recht. In einer Anklage wegen Ehebruchs gegen die Frau und ihren beschuldigten Liebhaber beispielsweise stritt die Frau jegliche Verbindung mit dem Mitangeklagten ab. Trotz dieser Aussage entschied der traditionelle Richter (im nördlichen Ngoniland ${ }^{49}$ ) gegen sie und stellte den Ehebruch fest. Der Richter hatte seine Begründungen oder das angewandte traditionelle Recht nicht erläutert. Der Gerichtsinspektor

Für Malawi keine Statisken vorhanden. Für Botswana, siehe Survey (1988 and 1993), "Top National Civil Servants Working Out in Districts, Number of Years of Education": "Most civil servants have 12 years and below of education." (aus Daten gesammelt von John Holm, a.a.O.).

Das ministerielle Personal wohnt in Städten, nicht auf dem Land. Es bewegt sich in ländlichen Gebieten nur auf Inspektionstour (oder im Urlaub beim Familienbesuch). Der entscheidene Punkt hier ist die Entfernung einer verstadtlichten Bürokratie von der Basis, nicht eine Stadt/Land-Trennung wie bei Max Webers (Rechtssoziologie) Vergleich zwischen römischen und deutschen Rechtsentwicklungen. Passender ist Webers Beobachtung über die Distanz zwischen römischen Konsulenten und englischen Advokaten. S. Max Weber, Rechtssoziologie, Heinz Maus und Friedrich Fürstenberg (Hrsg.), Neuwied am Rhein/Berlin, Hermann-Luchterhand Verlag, 1967, 2. Auflage, 1967), 254, 255.

49 Inspection File. Mzuzu. Ezondweni Traditional Court, File 319, opened 27 Dec 1985: from District Traditional Courts Officer, Mzimba North, 19 Apr 1994, Ref. No. MZU 3/1/9/103, to Traditional Courts Commissioner, Mzuzu, re: Ezondweni Traditional Court, Case No. 47/94, Complaint 71/1994. Answer from Chief Traditional Courts Commissioner, Ref. No. HQ/2/1/9/61, 24 May 1994. Vgl. Franz von Benda-Beckmann, Rechtspluralismus in Malawi: Geschichtliche Entwicklung und heutige Problematik, München, Weltforum Verlag, 1979, 31 (Eine Frau lügt nicht.). Interview, Sep 1994, mit Sheriff, Magistrates Court, Mzuzu (ehem. Traditional Courts Inspector): "in 1976-79 there was in the south of the country a number of murders by husbands of lovers of their wives because men with money were enticing married women away. This is an offence known under customary law as interference with the family. It had been punishable with nominal fees, but to stop this practice of men saying to their wives, do not plant this plot, I am saving it for my second wife, meaning he was going to entice a married woman to become his second wife, it was thought to raise the fines from Kwacha 18 to Kwacha 400 ... Maybe (the Commissioner) was right, it was a borderline case [siehe vorherigen Fall, 71/1994], but the man showed interest in the woman by paying her directly the debt instead of her husband. This would have been a case surely of interference with the family, for that could lead to adultery (a separate offence)." 
stimmte dem Ausgang der Entscheidung nicht zu und argumentierte, er habe in seinem Kurs über traditionelles Recht gelernt, daß unter den Ngoni das Wort einer Frau, die den Ehebruch abstreitet, den Prozeßausgang bestimmt. Der Inspektor wollte, daß diese Entscheidung rückgängig gemacht würde. Die Angelegenheit ging an den Chief Commissioner, der, wie auch der Inspektor, ursprünglich aus einer Gesellschaft stammt, in der die Abstammungslinie der Frauen wichtiger ist, als die der Männer. Der Chief Commissioner bestätigte das Urteil mit der Begründung, daß Indizienbeweise, wie sie in englischen Verfahren zum Beweis des Ehebruchs erlaubt sind, auch im traditionellen Recht anerkannt seien, und daß der Richter das Recht habe, die Indizien den anderslautenden Aussagen der Frau vorzuziehen. Als grundlegenden Standard, an dem das traditionelle Recht zu messen sei, nahm der Chief Commissioner das rezipierte Recht.

Wenn die Umstände des Falles vor einen anderen traditionellen Richter kamen, der aus einer Familie mit einer Tradition als Rechtsberater für Häuptlinge stammt ${ }^{50}$, und der ebenfalls den Kurs über traditionelles Recht an der Government School of Administration besucht hatte, so wurde das traditionelle Gesetz völlig anders ausgelegt: Ehebruch ist eine Frage der Einmischung in die Familie und der Ernsthaftigkeit der Frau über ihren Seitensprung. Wenn die Frau den Vorwurf des Ehebruchs nicht abstreitet, so beweist dies, daß sie ihren Ehemann verlassen will. Entsprechend ist die Abfindung, die ihm für den Ehebruch zusteht, relativ hoch. Streitet die Frau den Ehebruch ab, so beweist dies, daß sie ihren Ehemann nicht verlassen will. Wenn jedoch der Ehemann darauf besteht, Beweise vorzubringen, die den Richter vom Ehebruch überzeugen, und er dann nur auf Abfindung, nicht auf Scheidung klagt, so bedeutet dies, daß der Ehebruch die Ehe nicht ernsthaft gefährdet, und die Abfindungssumme ist niedriger als wenn die Ehefrau den Ehebruch zugibt. ${ }^{51}$

Selbst wenn der Fall aus der Heimatgegend eines Inspektors oder des Chief Commissioner kommt, so wird als Grundstandard noch immer der britische Standard des Billigkeitsrechts ("equity") gebraucht. ${ }^{52}$ Ehescheidungsprozesse beispielsweise sollten nach der Gewohnheit im Heimatbezirk der Frau angesetzt werden, denn man sagt, daß alle Vernehmungen zu Verhandlungen über eine Heirat im Dorf der Frau stattfinden. In einem Scheidungsfall beantragte die Frau die Verhandlung außerhalb ihres Heimatbezirks. Der Inspektor wollte,

Vgl. auch A. C. Unomah, Indirect Rule and the Nyamwezi Traditional System in the Tabora Province of Tanganyika, in Obaro Ikime and Segun Osoba (eds.), Tarikh. Indirect Rule in British Africa, 1970, vol. 3, No. 3, London, Longman, 57, 59: "Secondly, in the appointment of paramount chiefs more regard was paid to personal qualities than to the qualification, according to traditional usage, of the persons appointed to such posts." (57) "The basic aim of Cameron's administration was thus defeated to some extent. Although the paramount chiefs were meant to represent the traditional institutions, they were little different ... from the akidas ..." (59).

Emcisweni Traditional Court, Civil Case 387/82, Complaint 203/82, Interviews, Juli und Dez. 1993, Traditional Court Richter Mpherembere.

52

Interviews, Traditional Court Inspectors, Lilongwe und Mzuzu. 
daß der Fall an ihr Heimatgericht verlegt würde, wie es das traditionelle Recht vorsah, aber der Chief Commissioner widersprach ihm mit der Begründung, die rezipierte Equity des englischen Rechts erfordere zu berücksichtigen, welche Ausgaben die Frau auf sich nehmen müsse, wenn sie gezwungen würde, in ihren Heimatbezirk zurückzukehren. ${ }^{53}$

Die Erklärungen der leitenden Beamten (Traditional Court Commissioners und Inspectors) zum traditionellen Recht ${ }^{54}$ sind für die Richter an traditionellen Gerichten verbindlich. Ob die Richter diese Erklärungen zum traditionellen Recht tatsächlich akzeptieren und anwenden, hängt von einer Vielzahl von Faktoren ab. Hier scheint die Biographie eine größere Rolle zu spielen, wie auch die Motivation, ein Richter zu werden. Die traditionellen Richter, die aus Familien mit einer Tradition als Rechtsberater (Councillors) kommen, haben größeres Vertrauen in ihre Argumentationsfähigkeiten und geben daher detaillierte traditionelle Gründe für ihre Entscheidungen. ${ }^{55}$

Die zweite Gruppe von Richtern sind jene, die die Stellung aufgrund von Verbindungen zu der regierenden politischen Partei erhielten, oder die ihre geringen Einkommen aus der Landwirtschaft/Fischerei oder ihre geringen Renten aufbessern mußten (in Botswana beispielsweise ist die Arbeit als traditioneller Richter sehr beliebt unter den ehemaligen Poli-

Memo. From the Chief Traditional Courts Commissioner, Ref. No. HQ 2/19/1/165, 16 Jul 1982. To Traditional Courts Commissioner, Limbe, Transfer of Civil Case No. 524/82 Bwanali v. Bwanali, Blantyre Traditional Court: "... the female spouse came from a district other than Blantyre. Generally, in matrimonial cases it is the female spouse's customary law that is applicable at the court of jurisdiction at her home ... I do not think that I shall be doing justice to the spouse if I transfer it to a court which has not been identified by the female spouse whose customary home has never been introduced to the male spouse ... I do not think to do so would be out of step with section 12 of the Traditional Courts Act ... that the Traditional Courts will administer the customary law prevailing in the area of jurisdiction of the court, so far as it is not repugnant to justice ... [T] here is a 5 year child of the marriage and to cause the parties to incur further costs might affect this innocent child ..."

Definitionen von "customary law": Laws of Malawi (1976), Cap. 1:01 General Interpretation, "§2.-(1) "customary law" means the customary law applicable in the area concerned, ..." [In der Praxis bedeutet "area" einen Umkreis von 10 Kilometem (Memo Ref. HQ6/3/1/249, Jan 1974 from The Chief Traditional Courts Commissioner to All Traditional Courts Comsissioners).] The Laws of Botswana (1989), Cap. 16:01 Common Law and Customary Law: "§4. (1) Customary law, as comprised in the laws of Botswana, consists of rules of law which by custom are applicable to any particular tribe or tribal community in Botswana, not being rules which are inconsistent with the provisions of any enactment or contrary to morality, humanity or natural justice."

Interviews, Aug 1993, Aug 1994, 1) Traditional Court Chairman, Chiwenga: "I took over from my granny who was also in the Chamber at one time. My father was a chief in the village." 2) Traditional Court Assessor, Mpherembere: "The Court Chairman's father was an iduna. He had been the Chiefs advisor, so people had trust in him." Weitere Interviews, Dez 1993, Aug 1994, mit Traditional Court Clerk, Luzi (Malawi) und Sub-Chief (Onkel des Chiefs), Tribal Secretary Customary Court, Assessors, Customary Court, Good Hope (Botswana). 
zeibeamten ${ }^{56}$ ). Sie lassen den Gerichtsschreiber einfach die Verfügung und das Urteil ausstellen, ohne Begründungen zu geben. Man glaubt manchmal, die Nichtangabe von Gründen erlaubte es, der Kontrolle zu entkommen, da eine fehlende Begründung es dem leitenden Inspektor schwer macht, festzustellen, ob die Anweisungen des Ministeriums eingehalten wurden. Manchmal fehlen die Begründungen für ein Urteil, nur weil ein Richter sich nicht über die Feinheiten des traditionellen Rechts sicher ist.

Was die zwei Gruppen von Richtern gemeinsam zu haben scheinen, ist ihre Verinnerlichung der englischen Regeln des Zivil- und Kriminalverfahrens. Zuerst finden an einem zumeist vorher geplanten Zeitpunkt und Ort (dem Gerichtssaal) Anhörungen statt, vor

Interview, Dez 1993, Assessor, Chiwenga Traditional Court: "I wanted to do my job to resolve peope's problems ... although the driving force is eaming my living and that of my family." Interviews August 1994 mit Broadhurst Customary Court President (startete Karriere als Schreibkraft im Finanzamt). Siehe auch Zeitungsartikel "Customary court presidents should be given same respect as chiefs says district commission", Daily News (Gaborone), No. 105, 6 Jun 1994, p. 3; Traditional Courts Commissioner; zwei Polizisten, Gaborone. Dies entspricht der britishen Tradition, da $\beta$ die Polizisten staatsanwältige Aufgaben bei Strafprozeßen übernahmen. Seit neulich in Großbritannien nimmt die Staatsanwaltschaft die Aufgabe über. Rhodes House, Ross, a.a.O., 49: "Apart from Blantyre ... all courts were round thatched structures ... [I]nside were a raised platform for the judge or magistrates, and a table at floor level for prosecutor (Crown Counsel in High Court) (police of ficer in Magistrates' Courts). A District Commissioner usually tried his cases, ... without aid of a prosecutor or a "pleader" to defend accused, and on the whole it was remarkable how well the work was done and how few decisions required reversing or modifying." Siehe auch Regina v. Tembo, 1923-60 ALR (African Law Reports) Mal. 508 (vol 1) (1957): "The property in question belonged to the Police Officer who conducted the prosecution and he was, therefore, the principal witness not only in his capacity as a police of ficer and also.. as owner of the goods. It is always undesirable for the same person to be both prosecuting officer and a witness in a criminal case. It is appreciated, however, that in outlying districts in this country it is of ten impossible to find a prosecuting officer other than the investigating officer, so that in some cases there is no alternative other than for the prosecuting officer to give formal evidence in addition to conducting the prosecution. Where, however, the interests of the prosecuting officer are personally involved he cannot himself conduct the prosecution ... [T] he conviction cannot be allowed to stand." Vgl. ähnliche Beispiele aus Tanganyika, Rhodes House, H. Perry, Mss Afr s. 141 f. 324a-351 (1950s1960s), Handover Notes (n.d.), Voi Police Station: Cpl. 3609 Cornell is outstanding in his work in charge of all office literates and Records Of fice and his knowledge of law is first class, he is quite capable of carrying out a full investigation of serious crime ... and prosecuting it before a court." Handing Over, Prosecutions Branch, Mombasa (n.d.): "Traffic Magistrate Mr. J. Sweeney is retired Asst. Commissioner of Police." Mehrere britische koloniale Richter begannen ihre Karriere als koloniale Staatsanwälte, während sich in England (immer noch) die Richter aus der Rechtsanwaltschaft rekrutieren, nicht aus der Bürokratie, um die traditionelle Unabhängigkeit der Richter zu bewahren. S. Max Weber, a.a.O. (Rechtssoziologie), 239, über die Monopolisierung der richterlichen Beamtenstellen von Anwälten. Im Gegensatz zu England wurde die koloniale Richterschaft viel mehr bürokratisiert. Dadurch, so Max Weber, müßte es zu einer Beeinträchtigung der Unabhängigkeit der Richterschaft kommen (345ff). Auch Max Rheinstein, a.a.O., 12-13. 
allem, wenn einflußreiche Dorfbewohner einen Fall vorbringen. ${ }^{57}$ Einige Richter sind jedoch auch dazu bereit, für weniger einflußreiche Dorfbewohner, die, egal zu welcher Tages- oder Nachtzeit, eine schnelle Lösung eines Problems wünschen, auf die alte Art (ohne vorhervereinbarten Termin oder Ort) zu verfahren. ${ }^{58}$

Zweitens sind die traditionellen Gerichte, wie das englische Verfahrensrecht es verlangt, nicht mehr die Arenen, in denen die Zuschauer bei einer Anhörung an der Deutung der Beweise und der Auslegung der traditionellen Gesetze mitwirken können. Die Verinnerlichung dieser Regel ist besonders offensichtlich in Malawi, weniger in Botswana, wo der traditionelle Richter auf dem Lande oftmals der Öffentlichkeit erlaubt, ihre Meinung kundzutun, weil er sich so eher ein Bild davon machen kann, wer aus seinem Dorf einmal als Berater oder Sachverständiger arbeiten könnte, den er dann dem High Court empfehlen könnte, wenn vor diesem eine traditionelle Angelegenheit verhandelt wird.

In den traditionellen Gerichten der städtischen Randbezirke aber gibt es keine genügend zusammenhängende Dorfgemeinschaft, die Anhörungen besuchte, um ihre Meinung anzubieten.

Das strengere Aufsichtssystem und die vollziehende Kontrolle über die Ernennungen in Malawi ist vermutlich der Grund für diesen Unterschied zwischen den beiden Ländern. Die Teilnahme der Öffentlichkeit an traditionellen Gerichten in Malawi kann jedoch eine veränderte Form annehmen, wie zum Beispiel bei den Mangochi Yao. Die Zuschauer, insbesondere die Frauen, zeigen ihre Zustimmung oder Ablehnung dadurch, daß sie in die Hände klatschen. 59

57 Plantagenbesitzer vor allem, die nicht in das Dorfleben eingebunden sind. Beobachtungen bei Gerichtsverfahren in Mpherembere und Gespräche mit Richtern/Assessoren bei Gerichtsverfahren am 26. und 27.08.93.

Vgl. den Fall von Polizisten, die den Magistrate Sir Bryan Roberts, a.a.O. (Jun 1994), zu Hause besuchten, um Unterzeichnung eines Durchsuchungsbefehls zu erhalten, weil ein Radiowecker in einer Hochhauswohnung den ganzen Tag klingelte. Interviews, Dez 1993, Aug 1994, mit Häuptling, Luzi, über eine Frau, die in der Mitte der Nacht kam, um ihren Mann wegen Zauberei zu verklagen; Interview, Jul 1993, mit Khaya Traditional Court Assessor: "... the process has changed because it has been formalized unlike in the past where the sitting of assessors took place anywhere." Interview, Jul 1994, mit Häuptling, Mpherembere: "Land disputes are settled at the house. All in the village come to the questioning time ... In witchcraft cases, we send the parties to witchdoctors to assist them. The (chief's legal councillor) sends a letter to the doctor who replies. (The parties) should see three doctors. Or we give marching orders [expulsion] to the bad man."

59

Interview, Aug 1994, mit Yao Khaya Traditional Court Assessor und Häuptling (über 80 Jahre alt), deren Mutter Königsmutter (Matui) war: "Most of the men are keen to come to the court for settling cases while more women are more keen to come to the court to listen to the case and clap hands for the one they are in favour of." Vgl. Carl Meinhof, Afrikanische Rechtsgebräuche, Berlin, Verlag der Berliner evangel. Missionsgesellschaft, 1914, 84: "Die Volksmenge äußert sich erst, wenn der Redner ganz fertig ist, und gibt durch ein kurzes Brummen kund, daß sie seine 
Je höher man im Gerichtssystem kommt, desto weniger haben die Rechtshonoratioren fundiertes Wissen über die Feinheiten des traditionellen Rechts. Selbst Sachverständige, die vom High Court hinzugezogen werden, um über das traditionelle Recht auszusagen, befinden sich in einer unterlegenen Position gegenüber einem High Court-Richter. ${ }^{60}$ Zunächst führt der Unterschied aufgrund der Bildung zu einem gewissen Respekt. Außerdem kann er nicht mit dem Richter diskutieren oder ein Kreuzverhör führen, und er weiß, da $ß$ den in Großbritannien ausgebildeten Richtern in gerichtlichen Rundschreiben geraten wird, dem Sachverständigen nicht sklavisch zu folgen. ${ }^{61}$ Die Sachverständigen werden zum größten Teil nicht aus traditionellen Familien ausgewählt, sondern haben kleine lukrative Brennholz- und Kohlehandlungen, Geschäfte, oder sind Lehrer, die englisch sprechen können. Während sie in ihren Dörfern für ihre rhetorischen Fähigkeiten bekannt sind,

Rede entgegengenommen hat." Interviews, Aug 1993, Aug 1994, mit Asessors, Traditional Court Chairman, Chiwenga (Malawi): "We do know 50\% of the parties involved in the cases. We know them as neighbours ... (The majority) have hardly any political, social or religious influence. There are cases where the public attending court cases made known to the Assessors and Court Chairmen what in their opinion the traditional law is or how the case should be decided ... [O]nce a decision is made, ... the public does not make it known to the judge or assessors what they think of the decision." Vgl. aus Tanganyika Rhodes House, Wilson, a.a.O. 10 May 1938, G.A. Mitchell to Judge Wilson re: New Circular Confidential No. 2 of 1938 for submitting reports on persons charged with murder: "Report A to include report on character of accused, possible motives and local popular opinion ..." Siehe auch Rhodes House, Ross (Nyasaland), a.a.O., 54-55: "I once prosecuted on a charge of murder the son of a village headman and a witchdoctor. The village had suffered from sore eyes, the young man had called a witchdoctor called Gibson to diagnose ... The diagnosis was the headman and one of his wives were the cause ... Cure was death of the two. Gibson led them to the bank of the neighbouring stream where he smashed their heads with a pounding stick. There was no resistance from them. The guilt of the two was not difficult to prove ... When Gibson was asked why sentence of death should not be passed on him, he said he was a doctor who did his duty to diagnose and cure. Both men were executed. They might have escaped capital punishment had it not been for the bad reputation of the district where the murders were committed, several "ritual" and other murders having occurred there not so long before."

60

Beobachtungen und Interviews, Sep 1994, mit Assessors aus Mochudi, High Court, Lobatse (Botswana). Vgl. Aussagen über Assessoren bei Traditional Courts, Malawi: 1. "There is disagreement with assessors only on points of facts. Usually assessors give in ... because their relation is subordinate. The Chairman is boss. But a wise chairman is supposed to listen to the assessors." (aus Interview, Dez 1993 mit Traditional Court Chiarman, Mjuma Village, Chikulamayamke); 2. "The Assessors do not have access to discussions with the Traditional Courts Commissioner. The Commissioner discusses and clarifies certain points or weaknesses with the Court Clerk and the Court Chairman." (aus Interviews, Aug 1993 und Aug 1994, mit Assessors, Chiwenga Traditional Court).

Vgl. Nyasaland Protectorate Law Reports (1940-1945), Rex v. Moffat, Crim. Case 53/44, 51, Ag CJ Mathew, 16 Jan 1945: "Accused charged with murder of son-in-law ... Body never found ... Assessors are convinced that (son-in-law) is dead and with their opinion I agree ... Maondetsa (wife of deceased), Mchowa and Bemard impressed me as witnesses to the truth." Fußnote: "A month after conviction of (accused), the murdered man was found alive in Johannesburg. The convicted man was pardoned. Majority of witnesses sentenced to 7 years imprisonment for perjury. This illustrates the extreme care that must be taken particularly in native cases, of convicting for murder where the corpus delicti has not been found." 
haben sie in einem nach britischem Modell konzipierten Gericht keinen Raum, ihre Fähigkeiten zum Ausdruck zu bringen. Sie dürfen nur dann sprechen, wenn sie dazu aufgefordert werden. $^{62}$ In solch einer einschüchternden Atmosphäre hängt viel vom Charakter des vorsitzenden Richters ab. Hat er ein positives und nachdrückliches Interesse an traditionellen Gesetzen, so sind seine Fragen an den Sachverständigen tiefgehend.

Einer der in Großbritannien ausgebildeten afrikanischen Richter in Malawi hat z. B. gelernt, nicht einfach nur Fragen über abstrakte Regeln zu stellen. ${ }^{63}$ Er stellt Fragen über Symbole. In einem Heiratsfall bekam er beispielsweise als Berufungsrichter von Sachverständigen widersprüchliche Informationen darüber, ob das Gesetz der Ngoni es erlaube, daß eine Witwe ohne ihre weitere Zustimmung erbe. Als er jedoch danach fragte, welche Zeremonien stattgefunden hatten, was für Dinge ausgetauscht worden waren und was die betroffenen Parteien körperlich getan hatten, bekam er eine einstimmige Antwort. ${ }^{64}$ In diesem Fall hing das Recht von einem Bündel Stöcke ab, die der Witwe übergeben wurden, und davon, wie sie ihre Ablehnung durch Weggeben der Stöcke ausdrückte. In einem anderen Fall um eheliche Gütertrennung fragte derselbe Richter nach Fabeln und Liedern über Streitigkeiten zwischen Männern und Frauen und darüber, wie sie ihren Besitz aufteilten, wenn sie sich trennten. ${ }^{65}$ Einen Weg zu finden, traditionelles Recht auf andere gesetzliche Symbole zu übertragen, als jene, die wir in unseren westlichen Systemen haben, ist also ein Gebiet, das noch erforscht werden muß. ${ }^{66}$

Zusätzlich zu den Sprach- und Bildungsunterschieden haben die Sachverständigen bei der Erläuterung des traditionellen Rechts in einem High Court noch einen weiteren Nachteil zu bewältigen, der darin besteht, daß sie nicht genau wissen, ob die Parteien eines Falles in das Dorf, aus dem sie kommen, eingewandert sind. Der städtische High Court-Richter will

Interviews, Dez 1993, mit High Court Richter, ehem. Mitglied Traditional Court of Appeal und ehem. Registrar High Court.

Vgl. Chanock, a.a.O., 197: Widersprüchliche Aussagen werden eher als politisch bedeutend hervorgehoben.

Ein anderes Beispiel aus Christopher F. Kamlongera and Wales B. Mwaza, An Anthropology of Malawian Literature for Junior Secondary, Blantyre, Dzuka Publishing Company, 1993, 12 (Lied): "Go and marry a second wife/ So that I can be free/ So that I can be free/ What a husband! Greedy as a wild pig/ You make me pound maize when my palms hurt/ Go and marry a second wife/ So that I can be free." Siehe auch Kunni Kooijman, A Report on the Village of Bokaa, Botswana Extension College, 1978, 18: "At night stories were told and traditional songs sung. Singing was a major means of communicating wisdom and knowledge. Today this no longer exists."

66

Aber mit einer deutlicher Trennung zwischen Zeremonie und Magie. Vgl. Thurnwald, a.a.O., 11: "Uns mag eine solche Zeremonie als Ausfluß magischen Denkens erscheinen. Sie ist aber vielmehr der Ausdruck einer traditionellen Bedeutungsgeladenheit und Umschriebenheit des Handelns ..." 
lediglich nur die generelle Gruppenzugehörigkeit wissen. ${ }^{67}$ Ein Immigrantenstatus ist aber wichtig, da der traditionelle Richter ihnen dann mehr Spielraum läßt, um beispielsweise über die Abfindung für Ehebruch oder Schwängerung zu verhandeln, während für "Ortsansässige" dieser Betrag vom Dorf festgelegt wird. ${ }^{68}$

Ein Verfahrensmerkmal, das den afrikanischen Richtern am High Court und an den traditionellen Gerichten ungeachtet ihres Ausbildungsniveaus gemeinsam ist, ist die Art des Kreuzverhörs. ${ }^{69}$ Dies ist besonders bemerkenswert in Botswana, wo man noch immer die

Weber, a.a.O. über Stadt/Land-Trennung oben.

Civil Case 112/83, Complaint 133/83, Emcisweni Traditional Court (Malawi): "Ordered: The defendant is ordered to pay kwacha 32, payable by installments, for elopement. Explanation: The fine for elopment varies from $30 \mathrm{kwacha}$ to $308 \mathrm{kwacha}$. (The people of Mpherembere decided kwacha 208 for a woman not married and kwacha 308 for a married woman ... [O]ne can then settle in the clerk's office without going to proceedings. In another part of (this district of) Mzimba the father or guardian of a woman brings the charge and can decide how much he will ask for damages. He can differentiate between pregnancy, elopement, adultery damages according to which is a more serious offence." Interview, Aug 1994, Sub-Chief, Customary Court, Good Hope (Botswana): "The Kgosi (chief) in consultation with the people (belonging to the kgotla) can amend some customary law -- for example in compensation for seduction." Gerichtsverfahren, Emcisweni, 27.08.93: "Father: I charge defendant, husband of my daughter, with failure to give me information about her whereabouts. Husband: I gave you the information. She ran away to another man in the city. Father: But I want my daughter back. You must bring her back. Court: Ordered that the father make a search together with the husband to establish whereabouts of daughter and secure her return." Interview mit Richter: "The father worked many years in South Africa where his daughter grew up. On retirement he returned to his home village with the children. They are accustomed to doing as they like as in South Africa. The daughter married a poor farmer (no shoes in the courtroom, but the father had nice clothes) in the village. The father has not taught his daughter the manners and customs of our village. So he has, in this case, to take responsibility too for the whereabouts of the daughter not just the husband (as would normally have been the case)." Emcisweni Court, Civil Case 395/83, Complaint 432/79: "The wife is Ngoni, the husband Chewa, who owns an estate. They married out of love. This is not in our custom. So they do not (have) to go to the family to settle their differences." Auch ähnliches Urteil in Civil Case 240/94, Complaint 264/94: "Order divorce for wife. Her husband was not allowed two wives (because of his religion). Given without reconciliation attempts." Interview: "The parties live in Ngoniland, but are not (behave as) really Ngonis." Vgl. Urteil vom Court of Appeal of Botswana at Lobatse, Civ. App. No. 10/91, In the matter between: Kweneng Land Board v. Kabelo Listers Matlho and Pheto Motlhabane, 2 Dec 1992: "Tribal Land Act §2 "customary law" in relation to any land, means the customary law of the place where the land is situated. It seems clear in my view ... the Act is saying that the customary law ... may be different ... even within the same tribe [Bakwena](11) ... Schapera generalised and was not shown to relate to the place where the land in question in the case is situated ... The Headman of the place where the land is situated tendered af fidavit evidence of the custom of the place, and he was not challenged on this. (15) ... In my view whatever the customary law might have been in the past in the area concerned in this case, the law had apparently developed to permit of private ownership by tribesmen of tribal lands." (16).

69

Beobachtungen in High Court, Lobatse (Botswana), Customary Court, Broadhurst (Botswana) und Traditional Court, Mpherembere (Malawi). Ein Beispiel aus Matrimonial Cause, High Court, 
"expatriate" (eingewanderte Europäer) : und die afrikanischen Richter gegenüberstellen kann. Wenn im Verlauf des Kreuzverhörs die Beweislage an Gewicht gegen eine der streitenden Parteien gewinnt, so besteht eine unausgesprochene Erwartung seitens des Richters und der Parteien, daß keine Verfügung erlassen wird, bis daß eine Partei die Niederlage mit der Begründung eingesteht, daß selbst er oder sie das Gewicht der Beweise anerkennt. Beispielsweise stellte sich im Verlauf eines Verfahrens wegen offensichtlichen Diebstahls vor einem städtischen traditionellen Gericht in Botswana heraus, daß es sich tatsächlich um einen Fall von Prostitution anstelle von Diebstahl handelte. Mitten im Verfahren wurde die Angeklagte gefragt, ob sie gelogen hatte. Sie gab es zu. Als man den traditionellen Richter fragte, ob er sie wegen Meineides anklagen wolle, lehnte er ab. Ähnlich geschah es auch in einem Scheidungsfall des High Court, bei dem ein in britischem Recht geschulter af rikanischer Richter den Vorsitz hatte, als der Ehemann vorgetäuscht hatte, die Eltern um Schlichtung gebeten zu haben. Während des Kreuzverhörs durch den Richter gab er seine Versäumnisse zu und verlor. Diese Beispiele bestätigen die Erfahrung mancher britischen kolonialen Richter, die von englischen Prozeßregeln unter den gegebenden Umständen in den östlichen und südlichen afrikanischen Gesellschaften abwichen, weil sie meinten, daß nicht so sehr die Glaub- oder Unglaubwürdigkeit eines Zeugen von Interesse sei, sondern

Lobatse, Hearing, 4 Aug 1994: "Wif e: He beats me. Husband (ex- policeman): I love her. She beats me. I want to consult our parents to reconcile. [Nach weiteren Fragen] Court: So they have been already consulted after all and that brought nothing. Husband: I tried my best to reconcile. I leave it to the Court. Court: The Court can never persuade you and your wife to reconcile. Now only you and your wife can. Of course, if we divorce you, you can still persuade your wife to reconcile and remarry. Husband: I understand. Court: I grant a decree nisi." Aus dem Post-Urteil Interview: This case would have gone on even longer (already 2 years old) if the husband's request to go to parents had been granted. An expatriate judge would have been intimidated by the husband's request to consult the parents again. I think the husband would have continued beating the wife if the case dragged on as punishment for her applying for divorce. Vgl. Auseinandersetzung zwischen botsuanischem Staatsanwalt und "expatriate" Richter in R. Mosiakgabo and 8 ors., High Court, Feb 10, 1966, in Botswana Government Gazette, Supple D-E, 1968, E. 175. Emcisweni Traditional Court (Malawi), Debt Claim, 26 Aug 1993: "Defendant: I do not have to pay K 300 for medicines given to me for impotency. Plaintiff: In 1987 the defendant approached me for reproductive medicine. In 1987 a child was bom. Def.: It was born dead. I paid K 50. We got another child. It died. Plaintiff came to get his money at the burial. I gave $\mathrm{K} 50 \ldots$ We have now two children (alive). Plaintiff reminded me to collect medicine to continue (bearing). Court: Why do you refuse to pay for the medical services? Because a child died? Def.: No. Court: What if you pay K 300 and he gives you the medicine he still has for you? Def.: I cannot pay K 300 because of words he uttered to me. I can give if forced by the Court." Interview: "The defendant owns an estate and can afford to pay. He just wanted to pull out." S. auch Adam Kuper, South Africa and the Anthropologist, London, Routledge and Paul, 1987, S. 31. 
vielmehr die Feststellung der Gründe, warum er/sie lügt oder sich widerspricht. ${ }^{70}$ Der Richter spielt dann eine aktivere Rolle bei Feststellung der Tatsache, obwohl alle Richter

70

Sir Charles Becher (Judge, Nyasaland), a.a.O., 145: "The native lies to get himself or another out of trouble, rarely with intent to achieve his end at somebody else's expense. It may be a lack of intelligence, but he usually contents himself with a bare denial of his own part in the affair and the construction of a more or less barefaced alibi. The judge is not to ask: Ought I believe or disbelieve the witness - rather, why is the witness telling this kind of lie? Then the judge can come to a conclusion on what happened. [And]..there will be ample evidence to support his judgment." $S$. 243: "No "colonial" judge of any experience in assessing the value of the evidence given by a particular witness, gives the least weight to the fact of an oath having been taken or not taken. But still, he has in public to pretend that he does, ... [A]n appeal tribunal (whose members may not have had a great deal of practical experience) is very apt to pounce on discrepancies between two sets of evidence given by one witness and decide out of hand against his side, so that serious injustice results." Vgl. Richard Thurnwald, Die Menschliche Gesellschaft: Werden, Wandel und Gestaltung des Rechts im Lichte der Völkerforschung, Berlin/Leipzip, Walter de Gruyter, 1934, 178; Carl Meinhof, a.a.O., 88: "Ich glaube, man hat Ursache, auch dem Geständnis eines Afrikaners gegenüber vorsichtig zu sein ... Sein Geständnis würde dann also nicht besagen, daß er sich bewußt ist, die Handlung begangen zu haben, sondern daß er von magischen Gewalten für schuldig befunden wurde." Vgl. Markus Dirk Dubber, The German Jury and the Metaphysical Volk, 43 The American Journal of Comparative Law, 1995, 227-271 (247) über preußisches Recht dazu. Für andere Beispiele von Verständnis seitens kolonialen Richter und Staatsanwälten für Abweichungen von "common law" Prozeßregeln siehe: 1. Ross, a.a.O., 53: "in one dreadf ul case which I had to try, a chief had ordered a witchdoctor to give second dose (of poison) to a woman who had regurgitated the first. This caused her death. He was tried on a capital charge, but for want of corroboration he had to be acquitted. I shall never forget the ring of black faces round the court, and I have often wondered what they thought of white man's justice which allowed a person so clearly guilty (as, indeed, he was) to go free. I should add that the giving of a second dose was, even by native custom, not permitted ..." Ross, a.a.O. 60: "I believe that the Bench, both lay and professional, had the confidence of the African population, but I often wondered whether they thought the 'white man's law' was rather foolish, as indeed I often thought it was." Vgl. David Newman, Criminal Procedure and Evidence in Malawi, Mimeo, Zomba University of Malawi, Law and Practice Series No. 3, 1982, über tatsächliche Abweichungen ("Hearsay") nach der Unabhängigkeit. 2. Interview, Roberts, Jun 1994: "Q.: Do you think that Malawian Traditional Court judges have difficulty accepting the English presumption of innocence in criminal cases, for it is said the customary rule is, where there is smoke there is fire? A.: I as a judge listen (not presume). Q.: The hearsay rule has also caused problems. A.: (The Government) felt the strain of British hearsay procedure (in not getting convictions). I (either have to) know how to weigh evidence or not ... The British courts are moving themselves towards informality. Q.: Why were not juries accepted? A.: It was said that one's peers would come from the same area as the accused and they could not be objective, but the original meaning of jury in English law was precisely that, that one be judged by those of status similar to that of the accused." Hingegen: 1. Rhodes House, Wilson, a.a.O., 10 May 1938, G.A. Mitchell to Judge Wilson re: New Circular Confidential No. 2 of 1938 for submitting reports on persons charged with murder; Report A to include report on character of accused, possible motives and local popular opinion: "As an amateur magistrate endeavouring to administer justice I was very surprised to be called upon to report on character of accused before he stood trial, as I felt character and motives might be important issues at trial. I confined my report (A) to a short history of earlier life of accused ... and I added I would submit details of character and motives in report $\mathrm{B}$ in event of conviction. I shall probably receive reprimand from HQ for not following details, but it is difficult to obey an order as an Administra- 
sehr gut darin geschult sind, am Ende eines Verfahrens zu verkünden, daß der Kläger die Beweislast trägt.

\section{Schluß}

Die Vorstellungen von Rechtshonoratioren, wie sie von Weber und Rheinstein in einem europäischen Kontext definiert werden, ist für den afrikanischen Kontext zu eng. ${ }^{71} \mathrm{Zu}$ nächst umfassen die Rechtshonoratioren in einer afrikanischen Umgebung nicht nur die offiziell am Gerichtsprozeß beteiligten Personen, also Anwälte, Richter, Schreiber, Übersetzer, den Staatsanwalt, die Häuptlinge und die Akademiker, sondern auch die Dorfgemeinschaft. $^{72}$ Von daher sollten meiner Meinung nach die Regierungen Malawis und Botswanas bei den Kursen, bisher exclusiv für Gerichtspersonal ${ }^{73}$, die Beteiligung der Dorfbevölkerung daran ermöglichen. ${ }^{74}$

tive officer which one feels is unjust as Magistrate ..." 2. Rhodes House, Michael Tadman (Colonial Police Service, Nyasaland, 1956-66), Mss Afr s. 1784 (48): "All 'political' cases had to be referred personally to the Attorney-General for instructions and they were invariably marked 'no further action'. Two cases I recall of rape disposed of in this way ... Worst part of business was having to explain to complainants that the police were powerless to help them. This was a very unhappy period of my career."

Max Weber, Rechtssoziologie, a.a.O., 247-50. Max Rheinstein, a.a.O. 5, 12, beschränkt sich auch nur auf Richter, Advokaten, Notare, Professoren, und Rechtsberater des Unternehmertums und der Finanz.

Thurnwald, a.a.O., 183, erhebt den Häuptling zum Rechtspfleger einer Gemeinschaft. Markus Dirk Dubber, a.a.O., 249, footnote 146. A. N. Allott, The People as Law-Makers, Journal of African Law, 1977, 1-23. Nguyen Van Tuong, Une loi référendaire est-elle soumise au controle de constitutionnalité?, Recueil Dalloz Sirey, 1996, 3e Cahier-Chronique, 17-19 (18).

Ministry of Local Government and Lands, Tribal Administration in Botswana. A Training Course for Chiefs' Representatives and Headmen, Gaborone, Government Printer, 1990; Kathy M. Higgins, Botswana. The Tribal Administration. A Training Needs Assessment, 1987; Paya, Traditional Courts Handbook, Malawi (n.d.); Ralph Kasambara, Traditional Courts Handbook, Blantyre, Civil Liberties Committee, 1994.

Interview, Sep 1994, mit Sheriff, Magistrates Court, Mzuzu (ehem. Traditional Courts Inspector): "When there is dissatisfaction with a Court Chairman, it is not so much due to the law or judgments as to disappointment that no local was appointed." A. Manyeula, a.a.O., 20: "Many abandon the kgotla because it works hand in hand with the government." Appendix: Interview No. 3 of 6.8.1979: "In the old (precolonial) days, the case had to be tried by the family head, if too tough, then the ward headman, who would present it to village headman if it proved tougher than anticipated. The village headman would ... present to the main (chiefs) kgotla. The Chief would decide ..." In Malawi wird Schlichtung ohne Anwesenheit von Gerichtspersonal erlaubt: Siehe Memo, from the Chief Traditional Courts Commissioner, HQ/6/3/1/197, 3 Sep 1971, "Adjudication without authority": "Section 27 of the Traditional Courts Act makes it an offence for any person exercising ... judicial powers ... It was agreed at the Dedza Conference that an administrative directive be issued clarifying this section ... of the Act ... [W] here there was a voluntary submission by both parties to the defendant as arbitrator to settle the differences bet- 
Die gerichtliche Sprache, die bisher von den offiziellen Rechtshonoratioren gebraucht wurde, darf nicht einfach eine Übersetzung von Begriffen sein, sondern muß auch eine Übertragung von zeremoniellen Symbolen enthalten.

ween them and assess the amount of compensation, if any, ... the defendant has not committed an of fence under this section. Therefore, if a village headman, who is an elderly respected and trusted man in the village, is asked constantly to settle small differences and disputes between the villagers by those villagers themselves and his decision is ... accepted by the parties concerned, there is no of fence if he does nothing else other than mere arbitration ..." 
The Reception of European Law in Malawi and Botswana: The Role of African Judges and Judiciary Staff

\section{By Christina Jones}

As part of the judiciary staff recruited by the British in pre-independence Malawi and Botswana, the African court clerks and translators played an important role in the reception of English court rules of procedure and decision-making at the level of the District Officer's courts and the chief's courts. The traditional chiefs themselves also changed their ways of deciding cases under pressure of fear of being deposed by a District Officer. Substantive changes in the legal customs were made, too, in response to the British politics of "tribal reserves", thus preventing the establishment of new settlements with their own variation of legal customs. Due to lack of funds for major changes, post-independence personnel and judicial structures continued along the lines of the received law. Executive control of developments of local regional legal customs remains strong, but has to be differentiated between traditional law supervisors who are close to the grassroots and those far removed. One area, where the received law has receded, both in higher courts and lower traditional courts, can be illustrated by the active role that the court chairperson or judge takes in cross-examination. Popular acceptance of rulings on legal custom depends on whether the judge comes from the area and duly acknowledges the role that the inhabitants of a given district have in determining what the legal custom should be. 